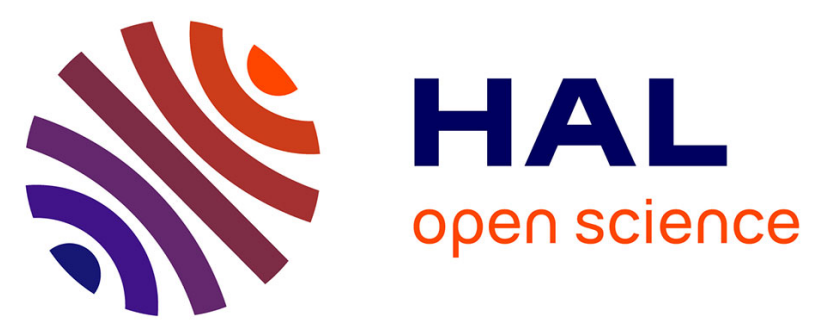

\title{
Planktonic ciliates in different water masses in open waters near Prydz Bay (East Antarctica) during austral summer, with an emphasis on tintinnid assemblages
}

Chen Liang, Haibo Li, Yi Dong, Yuan Zhao, Zhencheng Tao, Chaolun Li, Wuchang Zhang, Gérald Grégori

\section{To cite this version:}

Chen Liang, Haibo Li, Yi Dong, Yuan Zhao, Zhencheng Tao, et al.. Planktonic ciliates in different water masses in open waters near Prydz Bay (East Antarctica) during austral summer, with an emphasis on tintinnid assemblages. Polar Biology, 2018, 41 (11), pp.2355-2371. 10.1007/s00300-0182375-5 . hal-02024248

\section{HAL Id: hal-02024248 \\ https://hal-amu.archives-ouvertes.fr/hal-02024248}

Submitted on 20 Feb 2019

HAL is a multi-disciplinary open access archive for the deposit and dissemination of scientific research documents, whether they are published or not. The documents may come from teaching and research institutions in France or abroad, or from public or private research centers.
L'archive ouverte pluridisciplinaire HAL, est destinée au dépôt et à la diffusion de documents scientifiques de niveau recherche, publiés ou non, émanant des établissements d'enseignement et de recherche français ou étrangers, des laboratoires publics ou privés. 


\title{
Planktonic ciliates in different water masses in open waters near Prydz Bay (East Antarctica) during austral summer, with an emphasis on tintinnid assemblages
}

\author{
Chen Liang ${ }^{1,2,3,4} \cdot$ Haibo $\mathrm{Li}^{1,2,4} \cdot$ Yi Dong $^{1,2,4} \cdot$ Yuan Zhao ${ }^{1,2,4} \cdot$ Zhencheng Tao $^{1,2,4}$. Chaolun Li ${ }^{1,2,4}$. \\ Wuchang Zhang ${ }^{1,2,4}$. Gerald Gregori ${ }^{5}$
}

\begin{abstract}
Planktonic ciliates are important microzooplankton in pelagic ecosystems. Previous studies in Antarctic waters have only investigated ciliate assemblages in different habitats without considering water masses. In this article, we report the charac-teristics of ciliate assemblages in different water masses in open waters near Prydz Bay (East Antarctica) during austral sum-mer. Three water masses were identified according to temperature and salinity: Summer Surface Water (SSW), Winter Water (WW), and Circumpolar Deep Water (CDW). SSW was further divided into $\mathrm{SSW}_{\mathrm{Chl} a<3}$ (in vivo Chlorophyll $a>3 \mathrm{mg} \mathrm{m}^{-3}$ ) and $\mathrm{SSW}_{\mathrm{Chl} a<3}$ (in vivo Chlorophyll $a<3 \mathrm{mg} \mathrm{m}^{-3}$ ). Ciliate abundance and biomass in water masses decreased in the order: SSW $>$ WW $>$ CDW. $\mathrm{SSW}_{\mathrm{Chl} a>3}$ had a higher proportion (38.2\%) of tintinnids to the total ciliate abundance and larger aloricate ciliates (ciliates in the $10-20 \mu \mathrm{m}$ size class were $<15 \%$ of the total aloricate ciliate abundance) than in other water masses. WW had a higher proportion $(>30 \%)$ of Southern Ocean endemic tintinnid species in total tintinnid abundance than in other water masses. Each water mass had the following indigenous tintinnid species: SSW, Salpingella sp., Codonellopsis gaussi; WW, Salpingella costata, S. faurei, Cymatocylis affinis/convallaria forma drygalskii, and C. vanhoeffeni. Laackman-niella naviculaefera and C. affinis/convallaria forma cristallina were present at high abundance in both WW and $\mathrm{SSW}_{\mathrm{Chl} a>3}$. Upwelling caused discontinuity of the ciliate distribution. Our results will help predict the spatial and temporal variations of ciliate assemblages and other plankton according to the dynamics of water masses in Antarctic waters.
\end{abstract}

Keywords Planktonic ciliates $\cdot$ Abundance $\cdot$ Tintinnid $\cdot$ Water mass $\cdot$ Prydz Bay $\cdot$ Antarctica

Electronic supplementary material The online version of this article (https://doi.org/10.1007/s00300-018-2375-5) contains supplementary material, which is available to authorized users.

Wuchang Zhang

wuchangzhang@qdio.ac.cn

1 CAS Key Laboratory of Marine Ecology and Environmental Sciences, Institute of Oceanology, Chinese Academy of Sciences, Qingdao 266071, People's Republic of China

2 Laboratory for Marine Ecology, Qingdao National Laboratory for Marine Science and Technology, Qingdao 266237, People's Republic of China

3 University of Chinese Academy of Sciences, Beijing 100049, People's Republic of China

4 Center for Ocean Mega-Science, Chinese Academy of Sciences, 7 Nanhai Road, Qingdao 266071, People's Republic of China

5 Aix-Marseille University, Toulon University, CNRS, IRD, Mediterranean Institute of Oceanology UM110, 13288 Marseille, France

\section{Introduction}

Marine planktonic ciliates constitute a major, ubiquitous, and diverse group of protozoa. These organisms range from 5 to $200 \mu \mathrm{m}$ in length and can be divided into tintinnids and aloricate ciliates, which belong to the subclasses Oligotrichia and Choreotrichia, respectively, in the class Spirotrichea (Lynn 2008). As one of the main components of microzooplankton, ciliates are a trophic link between the microbial food web and the traditional food chain. Planktonic ciliates feed on nanoplankton (Heinbokel and Beers 1979; Capriulo 1983; Verity 1987) and picoplankton (Bernard and Rassoulzadegan 1993), while they are preyed upon by mesoplankton and fish larvae (Azam et al. 1983; Lavalpeuto et al. 1986; Pierce and Turner 1992, 1994). Thus, they play an important role in the transfer of energy and material through the entire pelagic food web (Beers 1967; Pierce and Turner 1992). 
The various genera of tintinnids have been divided into several biogeographical types (cosmopolitan, neritic, warmwater, boreal, and austral) according to their global occurrence (Pierce and Turner 1993; Dolan et al. 2013a). Therefore, different biogeographical areas can be characterized by different tintinnid assemblages ( $\mathrm{Li}$ et al. 2016). In the austral assemblage, Dolan et al. (2012) divided the austral species $\left(40^{\circ} \mathrm{S}-78^{\circ} \mathrm{S}\right)$ into Southern Ocean endemic species (only found south of $40^{\circ} \mathrm{S}$ ) and widespread species (those with a geographic range extending into the Southern Ocean). In Antarctic waters, ciliate abundance was observed in different habitats (oceanic areas, transitional areas, polynyas, edges of glaciers, and edges of sea ice) in the Amundsen Sea (e.g., Jiang et al. 2014, 2015, 2016) and the Weddell Sea (e.g., Heinbokel and Coats 1986; Garrison and Buck 1989; Garrison et al. 1991; Gowing and Garrison 1992). These investigations generally evaluated ciliate assemblages at a horizontal level while providing very little vertical distribution information. Plankton distribution has been found to be closely related to water masses (Longhurst 2007), and previous studies have provided evidence of different phytoplankton community structures in various water masses (e.g., Stoecker et al. 1992; Mura et al. 1995; Zhang et al. 2012). Although water masses are well defined in the Southern Ocean (Tomczak and Godfrey 1994), no studies have investigated the relationship between ciliates and different water masses in this ocean to date.

There are several vertically divided water masses in waters near Prydz Bay (East Antarctica) during austral summer; namely, Summer Surface Water (SSW), Winter Water (WW), Circumpolar Deep Water (CDW), Antarctic Bottom Water (ABW) and Antarctic Shelf Water (ASW) (Smith et al. 1984; Middleton and Humphries 1989; Le et al. 1996; Vaz and Lennon 1996; Williams et al. 2010; Shi et al. 2013). Moreover, upwelling occurs sporadically in Prydz Bay (Lin et al. 2016). Bathymetrically, there is a basin known as the Amery Depression located at a depth of about $700 \mathrm{~m}$ seaward of the Amery Ice Shelf that shoals gently to outer shelf banks at a depth of around $200 \mathrm{~m}$ (Gao et al. 2013). Few studies have investigated ciliate assemblage in Prydz Bay and its surrounding waters. Planktonic ciliates were investigated at 0 and $5 \mathrm{~m}$ below sea ice at two stations very close $(3 \mathrm{~km})$ to shore (Paterson and Laybourn-Parry 2012). In addition, ciliate abundances were determined at a depth of $15 \mathrm{~m}$ in Prydz Bay, $5 \mathrm{~km}$ offshore from the Australian Antarctic station of Davis (Davidson and Marchant 1992), but there is no record of tintinnid species in this area. However, there have been studies of phytoplankton, zooplankton, bacteria, and viruses in Prydz Bay and its adjacent areas without considering water masses (e.g., Zhu et al. 1994; Waters et al. 2000; Thomson et al. 2010; Liang et al. 2016). Moreover, Zhang et al. (2012) used flow cytometry to show that the SSC (side scatter, optical parameter) signal of picophytoplankton increased horizontally from out of the bay to a coastal station without considering the vertical division of water masses in Prydz Bay.

The notion that different water masses contain different indigenous species of plankton is the base of plankton biogeography (Longhurst 2007; Priede 2014), as well as the base of expatriate species (Angel 1993; Kobari et al. 2008), stray species (Dolan et al. 2012) and indicator species (e.g., Kato and Taniguchi 1993). Most of the biogeographical studies have been conducted in the horizontal division of water masses, however, we hypothesized that different ciliates have different preferred water masses in the vertical direction in Antarctic waters. Therefore, we compared the ciliate assemblages in different vertically divided water masses in open waters near Prydz Bay during austral summer. Our specific objectives were to compare (1) the contributions of aloricate ciliates and tintinnids to total abundance, (2) proportions of different-sized aloricate ciliates in total aloricate ciliate abundance, and (3) tintinnid species distributions in different water masses.

\section{Materials and methods}

Sampling was conducted at 34 stations in four South-North transects (P2, P3, P4, P5) in open waters near Prydz Bay $\left(65^{\circ} 28^{\prime}-73^{\circ} 3^{\prime} \mathrm{E}, 65^{\circ}-68^{\circ} \mathrm{S}\right)$ (Fig. 1) onboard the R. V. "Xuelong", during the late austral summer (3-27 February) of 2015. The study area was outside of Amery Depression and free of ice. The minimum and maximum depths of the stations were $102 \mathrm{~m}$ (St. P2-9) and $3991 \mathrm{~m}$ (St. P5-2), respectively. At each station, vertical profiles of temperature, salinity and in vivo Chlorophyll $a(\mathrm{Chl} a)$ fluorescence were determined from the sea surface to a depth of $300 \mathrm{~m}$ or $2 \mathrm{~m}$ above the bottom when the water depth was $<300 \mathrm{~m}$ using the SBE911-conductivity-temperature-depth (CTD) unit. Water masses were determined according to temperature and salinity (Smith et al. 1984; Middleton and Humphries 1989; Le et al. 1996; Vaz and Lennon 1996; Williams et al. 2010; Shi et al. 2013).

Water was sampled using 10-L Niskin bottles on a rosette CTD carrousel. Seawater samples of $1 \mathrm{~L}$ were collected from each sampling point (surface, 25, 50, 75, 100, 150, $200,300 \mathrm{~m}$ at each station), then fixed with Lugol's solution ( $1 \%$ final concentration, $\mathrm{vv}^{-1}$ ). A total of 264 water samples were collected.

In the laboratory, each water sample was concentrated to about $100 \mathrm{~mL}$ by gently siphoning out supernatant water after allowing it to settle for at least $48 \mathrm{~h}$. The settling and siphoning processes were repeated to concentrate each sample to a final volume of $\sim 50 \mathrm{~mL}$. The concentrated sample was then allowed to settle in an Utermöhl counting chamber 
Fig. 1 Sampling stations in open waters near Prydz Bay during the late austral summer. Red star Chinese Antarctic station of Zhongshan; Red circle Australian Antarctic station of Davis

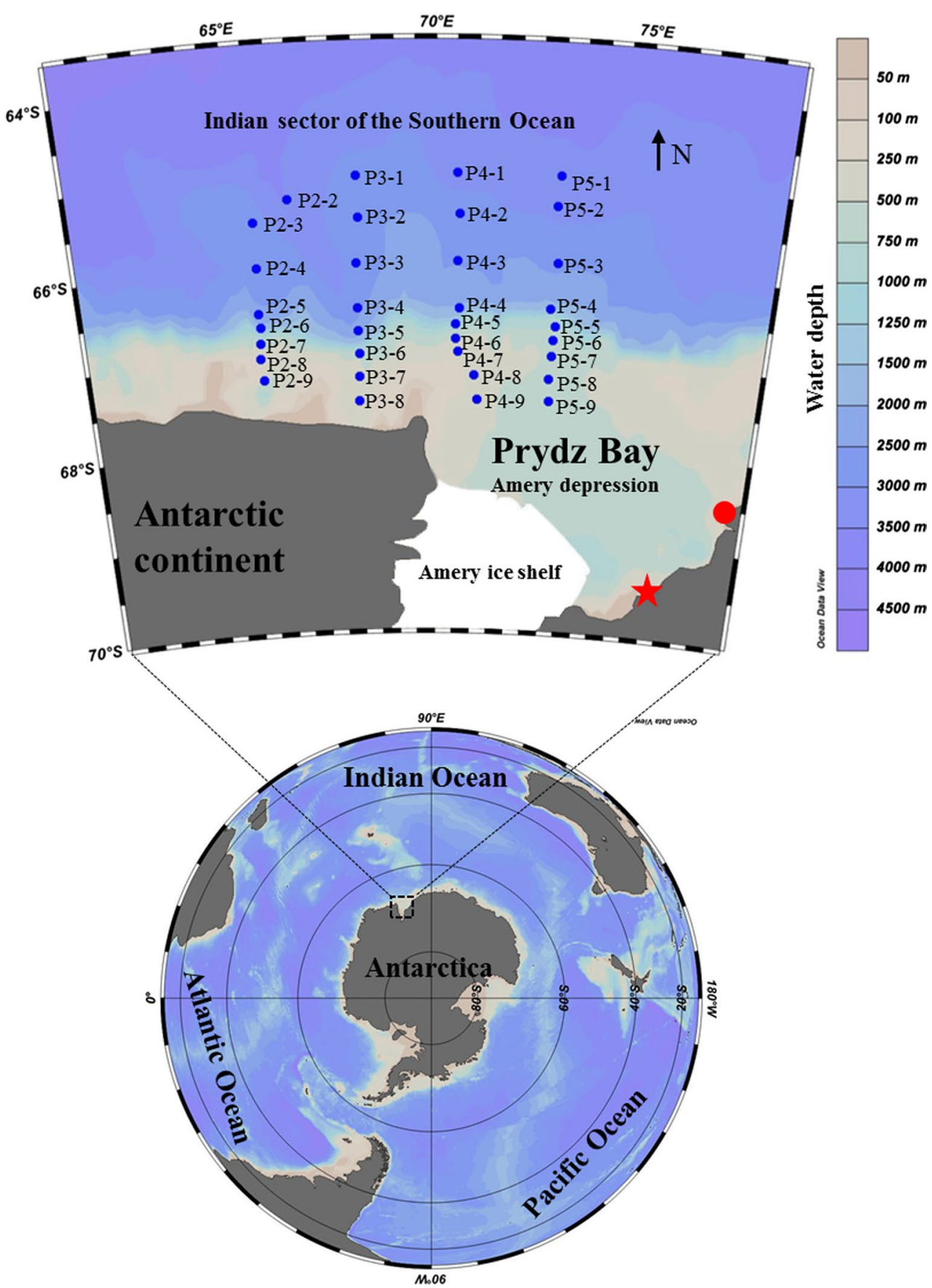

for at least $24 \mathrm{~h}$, after which it was examined using an Olympus IX 71 inverted microscope $(\times 100$ or $\times 400)$.

For each sample, the entire concentrated sample was counted. A maximum of $25 \mathrm{~mL}$ of the concentrated sample was examined in each count; therefore, at least two counts were made to complete sample analysis. A smaller volume was examined for each count when the microscopic view was blurred because of the high concentration of phytoplankton. The species present in low abundance (especially Antarctic endemic species of tintinnids) were counted completely in every count to ensure accuracy. Highly abundant species were not counted if a high number was obtained in a previous count. Because mechanic and chemical disturbances associated with collection and fixation procedures could provoke detachment of the protoplasma from the loricae (Paranjape and Gold 1982; Alder 1999), empty loricae of tintinnid species were counted as living cells in this study. In addition, some loricae might be empty when they were sampled (Kato and Taniguchi 1993; Dolan and Yang 2017), which might have resulted in overestimated numbers. 
For each species, sizes (e.g., length or width, according to shape) of the cell (aloricate ciliate) or lorica (tintinnid, especially length and oral diameter) were measured for at least (if possible) 20 individuals in the entire study area. According to lorica morphology and size, tintinnids were identified to the species level according to references (Laackmann 1910; Kofoid and Campbell 1929, 1939; Hada 1970; Boltovskoy et al. 1990; Alder 1999; Zhang et al. 2012; Dolan et al. 2013b; Kim et al. 2013). Ciliate volumes were then estimated using appropriate geometric shapes (cone, ball, and cylinder). Tintinnid carbon biomass was estimated using the equation: $C=$ lorica volume $\left(\mu \mathrm{m}^{3}\right) \times 0.053+444.5$ (Verity and Langdon 1984). The conversion factor of carbon biomass for aloricate ciliates used in this study was $0.19 \mathrm{pg}$ $\mathrm{C} \mu \mathrm{m}^{-3}$ as defined by Putt and Stoecker (1989). Southern Ocean endemic species were defined according to Dolan et al. (2012).

\section{Data analysis}

The occurrence frequency of each tintinnid species was calculated by dividing the total number of sampling points by the number of sampling points where this species occurred. Principal component analysis (PCA) was conducted using Canoco for Windows 4.5 software. For PCA, environmental variables included seawater temperature, salinity, Chl $a$ and depth, while biological variables consisted of the abundance of 13 tintinnid species. Cluster analysis was conducted using the Primer 5 software. Group-average linkage based on the Bray-Curtis similarity matrix of the fourth root transformed tintinnid abundances was utilized.

\section{Results}

\section{Hydrography and water mass division}

The water column temperature (Fig. 2) showed obvious sandwich structures, with warm water $\left(\mathrm{T}>-1.5^{\circ} \mathrm{C}\right)$ lying on and below a cold water $\left(\mathrm{T}<-1.5^{\circ} \mathrm{C}\right)$ layer. We defined the cold-water belt $\left(\mathrm{T}<-1.5^{\circ} \mathrm{C}\right)$ in the middle as $\mathrm{WW}$, the warm water upon WW in the upper $50 \mathrm{~m}$ as SSW, and the warm water below WW as CDW. Upwelling occurred in transect P3 (Sts. 6, 7), P4 (Sts. 4-6), and P5 (Sts. 3-6). The upwelling in transects P4 and P5 were stronger, with $-1.2{ }^{\circ} \mathrm{C}$ outcropping to the surface, while the upwelling was comparatively weak in Transect P3 with a temperature of only $-0.8^{\circ} \mathrm{C}$ outcropping to the surface. WW lied between 50 and $100 \mathrm{~m}$ on the offshore side of the transects, whereas it occupied the water column down to $300 \mathrm{~m}$ on the coastal side.

The salinity was less than 34 in the upper $50 \mathrm{~m}$ (SSW) at most stations, while WW and CDW exhibited higher salinity (>34) (Fig. 2). The position of salinity 34 isohaline was similar to that of the $-1.5^{\circ} \mathrm{C}$ isothermal underlying SSW. The in vivo Chlorophyll $a(\mathrm{Chl} a)$ decreased with depth, and the highest values $\left(>3 \mathrm{mg} \mathrm{m}^{-3}\right)$ were limited to coastal sites in the upper $50 \mathrm{~m}$ of SSW, with a maximum value of $19.18 \mathrm{mg} \mathrm{m}^{-3}$ being observed at $4.5 \mathrm{~m}$ at St. P5-9. According to the spatial distribution of the concentration of Chl $a$, SSW was divided into an area with Chl $a$ concentration $>3 \mathrm{mg} \mathrm{m}^{-3}$ near the shelf and another area with concentration $<3 \mathrm{mg} \mathrm{m}^{-3}$ in the north. The horizontal division of the two sectors overlapped with that of the upwelling, with the exception of transect P2, for which upwelling was not detected in SSW.

\section{Ciliate abundance and biomass in different water masses}

Ciliate abundance and biomass decreased from SSW to CDW (Table 1, Figs. 3, 4, 5a). High ciliate abundance (> 1000 ind. $\mathrm{L}^{-1}$ ) and biomass $\left(>4 \mu \mathrm{g} \mathrm{C} \mathrm{L}^{-1}\right.$ ) occurred in SSW. The aloricate ciliate proportion accounted for $>57 \%$ of the total ciliate abundance in all water masses. Average abundances of aloricate ciliates and total ciliates in $\mathrm{SSW}_{\mathrm{Chl} a>3}\left(\mathrm{SSW}, \mathrm{Chl} a>3 \mathrm{mg} \mathrm{m}^{-3}\right)$ were less than in $\mathrm{SSW}_{\mathrm{Chl} a<3}$, but their average biomasses were greater than in this fraction of water (Table 1, Fig. 5b). The proportion of tintinnids to the total ciliate abundance in $\mathrm{SSW}_{\mathrm{Chl} a>3}$ $(38.2 \%)$ was much higher than in any other water masses $(<13 \%)$, with CDW having the lowest tintinnid proportion (2.2\%, Fig. 5b). In addition, $\mathrm{SSW}_{\mathrm{Chl} a>3}$ contained larger sized aloricate ciliates, with those in the 10-20 $\mu \mathrm{m}$ size class compromising $<15 \%$ of the total aloricate ciliate abundance, while this value was more than $39 \%$ in other water masses (Fig. 5c).

Thirteen tintinnid species belonging to five genera were identified (Table 2, Fig. 6), and the occurrence frequencies and abundances of different tintinnids varied greatly. Generally, tintinnids with a higher occurrence frequency also had a higher abundance (both average abundance and maximum abundance, Online Resource 1). Salpingella sp. was the most abundant and frequent species, while Amphorides laackmanni was the least abundant (Table 2, Fig. 5d, Online Resource 1). Tintinnid total abundance in different water masses was different, with $\mathrm{SSW}_{\mathrm{Chl} a>3}$ having the highest average tintinnid total abundance ( 209 ind. $\mathrm{L}^{-1}$ ) among all water masses (Fig. 5d, Table 1). The average abundance of all tintinnid species in CDW was low $\left(<0.9\right.$ ind. $\left.\mathrm{L}^{-1}\right)$ (Fig. 5d, Table 2).

There were seven Southern Ocean endemic tintinnid species (Codonellopsis gaussi, Laackmanniella naviculaefera, Cymatocylis affinis/convallaria, C. antarctica, C. affinis/convallaria forma cristallina, C. affinis/convallaria forma drygalskii and C. vanhoeffeni). Laackmanniella naviculaefera 


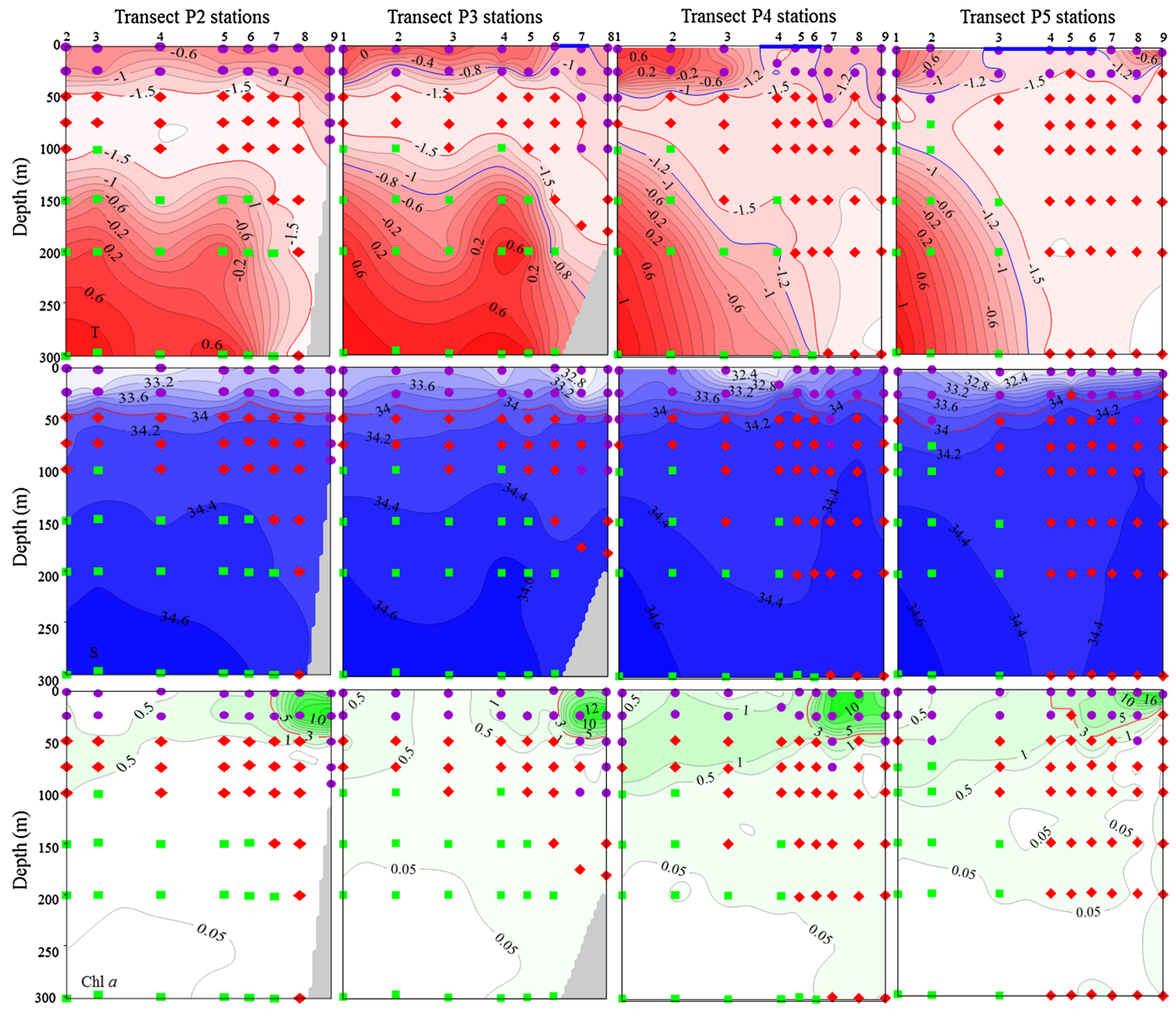

Fig. 2 Vertical distributions of temperature $\left(\mathrm{T},{ }^{\circ} \mathrm{C}\right)$, salinity $(\mathrm{S})$, in vivo Chlorophyll $a(\mathrm{Chl} a)$ fluorescence along the transects ( $\mathrm{P} 2$, P3, P4, P5) in open waters near Prydz Bay. Dot symbols indicate both the depths at which ciliates were sampled and the water masses where

and C. affinis/convallaria forma cristallina were the most abundant endemic species in WW (Table 2). The average abundance of endemic species in $\mathrm{SSW}_{\mathrm{Chl} a>3}$ was highest (Fig. 5d), and the Southern Ocean endemic species abundance in WW (>30\%) was much higher than in other water masses (Fig. 5e).

\section{Tintinnid species in different water masses}

Cluster analysis divided all tintinnid species into four groups according to their distribution (Online Resource 2 ). Species in groups I, II and III had higher occurrence frequencies, making it possible to study their distribution samples were collected (purple circle SSW; red diamond WW; green square CDW). Blue line: upwelling range at the 0-m depth. SSW: Summer Surface Water, WW: Winter Water, CDW: Circumpolar Deep Water

pattern. Three main patterns corresponding to the three groups were identified according to their distribution characteristics (Figs. 7, 8, 9). Pattern 1 was defined by tintinnids that mainly occurred in SSW. These organisms were distributed in the surface or subsurface layer of SSW, but disappeared in the deep water. Tintinnids with this pattern were identified as Salpingella sp. and $C$. gaussi. The maximum abundance of Salpingella sp. was observed in the upper $25 \mathrm{~m}$, while that of $C$. gaussi was found in the upper $50 \mathrm{~m}$ (Fig. 7, Online Resource 3). Pattern 2 was defined as tintinnids that mainly occurred in WW. These species (Salpingella costata, S. faurei, C. affinis/convallaria forma drygalskii and C. vanhoeffeni) did not exist in the upper $25 \mathrm{~m}$ and 


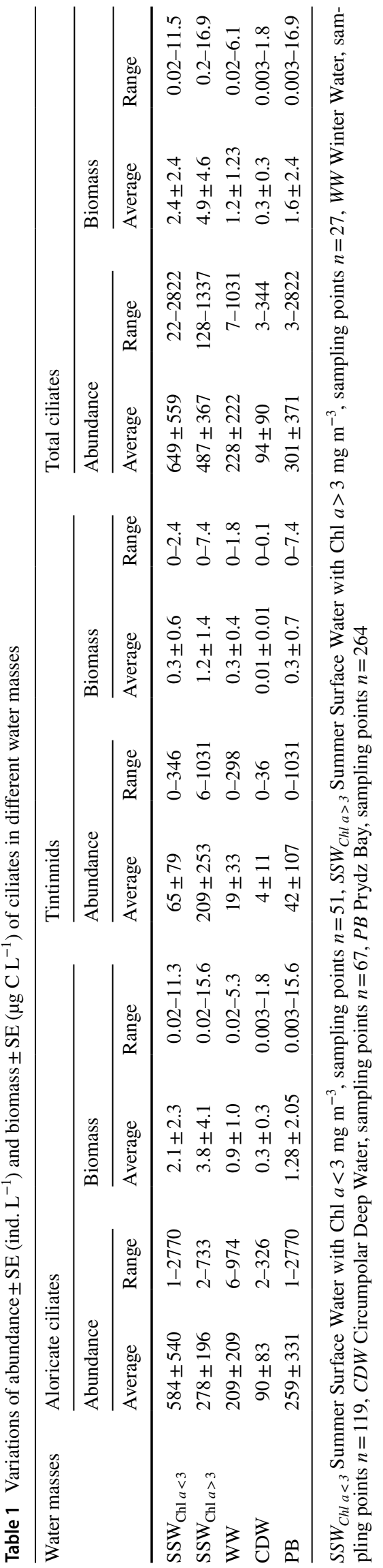

mainly occurred in the subsurface and stretched into deep water in WW in the coastal area, with a decreasing trend to the north (Fig. 8, Online Resource 3). Finally, L. naviculaefera and C. affinis/convallaria forma cristallina formed Pattern 3. These organisms inhabited both $\mathrm{SSW}_{\mathrm{Chl} a>3}$ and WW, and were distributed from the surface of $\mathrm{SSW}_{\mathrm{Chl} a>3}$ to deep water in WW (Fig. 9, Online Resource 3). These two species were the most abundant Southern Ocean endemic species in WW (Table 2). Species in group IV (Codonellopsis glacialis, C. affinis/convallaria, C. antarctica, Salpingella acuminata, and A. laackmanni) occurred too rarely (occurrence frequency $<8 \%$, Table 2) to show any obvious occurrence pattern (Online Resource 4).

Principal component analysis of the 264 samples and 13 tintinnid species was conducted to examine the contribution of the environmental variables to tintinnid species occurrence (Fig. 10). Two principal components discriminated the environmental conditions in three water masses. These components explained a large proportion $(68.1 \%)$ of the variance, as well as 44.7 and $23.4 \%$ of the tintinnid species variation, respectively (Fig. 10). The first principal component was closely related to seawater depth, Chl a, Salpingella sp., $C$. gaussi and $C$. glacialis. These three tintinnid species had a strong positive correlation with $\mathrm{Chl} a$ but a strong negative correlation with depth. Chl $a$ had the greatest influence on $C$. gaussi and $C$. glacialis. The second principal component was closely related to temperature, S. costata, S. faurei, $C$. affinis/convallaria forma drygalskii and $C$. vanhoeffeni, $C$. affinis/convallaria forma cristallina and L. naviculaefera. These species had a strong negative correlation with temperature (Fig. 10). Different tintinnid groups had different temperatures and $\mathrm{Chl} a$ preferences: those showing Pattern 1 occurring in warm water in the surface and those showing Pattern 2 being present in cold water. Tintinnid species in Pattern 3 occurred in cold water and warm water with high Chl $a$ levels (Online Resource 5).

\section{Discontinuity of ciliate distribution}

Isolines of low abundance of aloricate ciliates, tintinnids, and total ciliates showed upwelling in the corresponding horizontal position of the upwelling. The total ciliate abundance isoline of 200 ind. $\mathrm{L}^{-1}$ upwelled in transects P3, P4 and P5, and even reached the surface in SSW in transect P5. The aloricate ciliate isoline of 200 ind. $\mathrm{L}^{-1}$ was distributed in generally the same pattern as the total ciliate assemblage. The tintinnid abundance isoline of 40 ind. $\mathrm{L}^{-1}$ reached the surface in SSW and defined areas of low abundance in surface water for all transects (Fig. 3). According to the tintinnid distribution (Figs. 7, 8, 9), there was an obvious low-abundance division area that split the tintinnid abundance distribution into two parts. The Salpingella sp. abundance distribution in Transect P3 could easily be split into two parts by the 5 


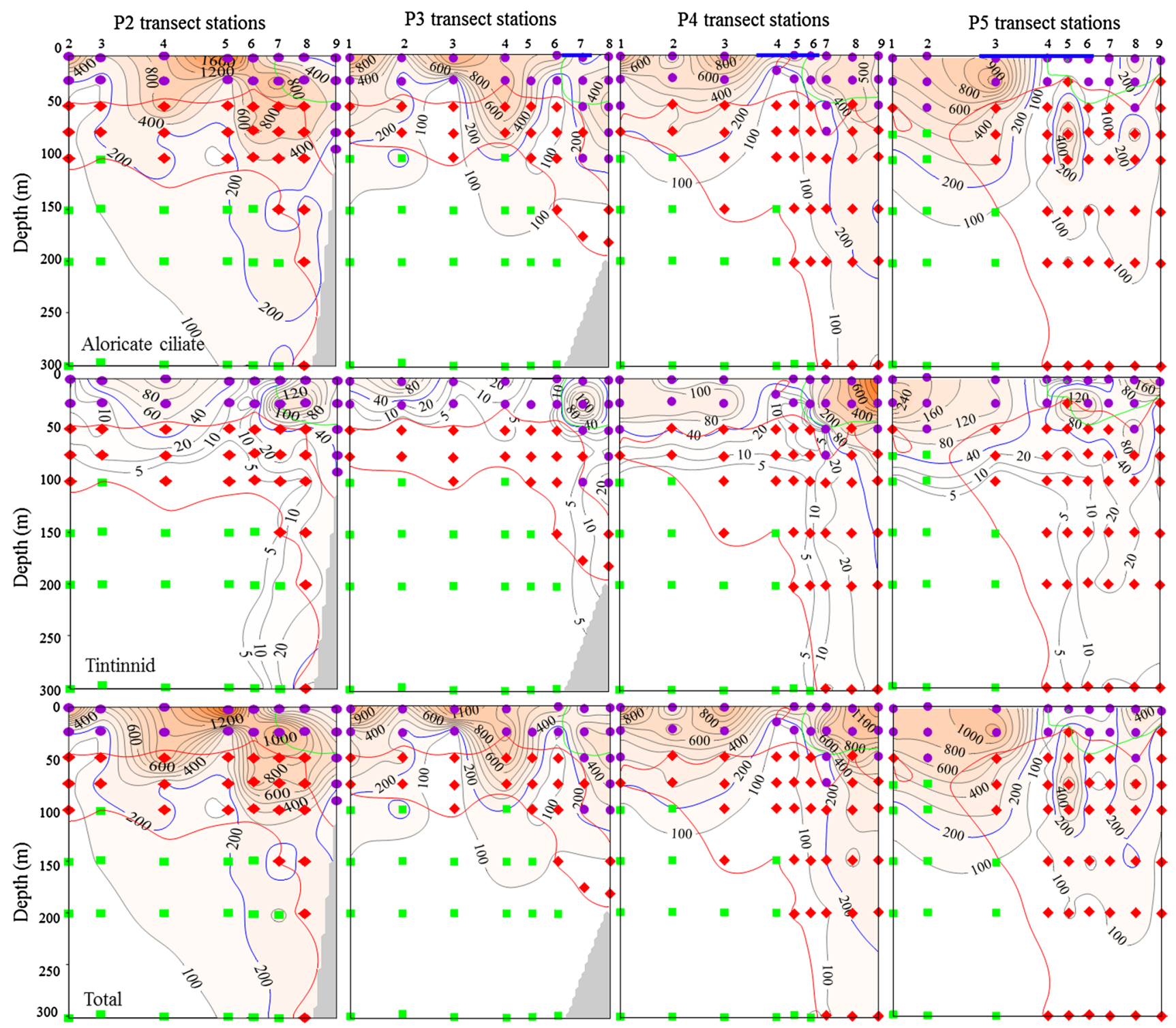

Fig. 3 Vertical distributions of abundance (ind. $\mathrm{L}^{-1}$ ) of aloricate ciliate, tintinnid, and total ciliate along the transects (P2, P3, P4, P5) in open waters near Prydz Bay. Dot symbols indicate both the depths at which ciliates were sampled and the water masses where samples were collected (purple circle SSW; red diamond WW; green square
CDW). Blue line: upwelling range at the 0-m depth. SSW: Summer Surface Water; WW: Winter Water; CDW: Circumpolar Deep Water. Red isotherm of $-1.5^{\circ} \mathrm{C}$ and green $\mathrm{Chl} a$ isoline of $3 \mathrm{mg} \mathrm{m}^{-3}$ were attached ind. $\mathrm{L}^{-1}$ isoline, while the 60 ind. $\mathrm{L}^{-1}$ isoline split Transect P4 and P5 into two parts (Fig. 7). In the case of tintinnids with Patterns 2 and 3 (C. affinis/convallaria forma drygalskii, C. vanhoeffeni, S. costata, S. faurei, L. naviculaefera and C. affinis/convallaria forma cristallina), their distribution area was also divided by low abundance isolines, and their abundance was higher on the coastal side of the cold-water upwelling (Figs. 8, 9).

\section{Discussion}

\section{Ciliate abundance and biomass in different water masses}

Data concerning ciliate abundance and biomass are scarce in open waters near Prydz Bay. Paterson and Laybourn-Parry (2012) reported a maximum ciliate abundance of 3000 ind. 


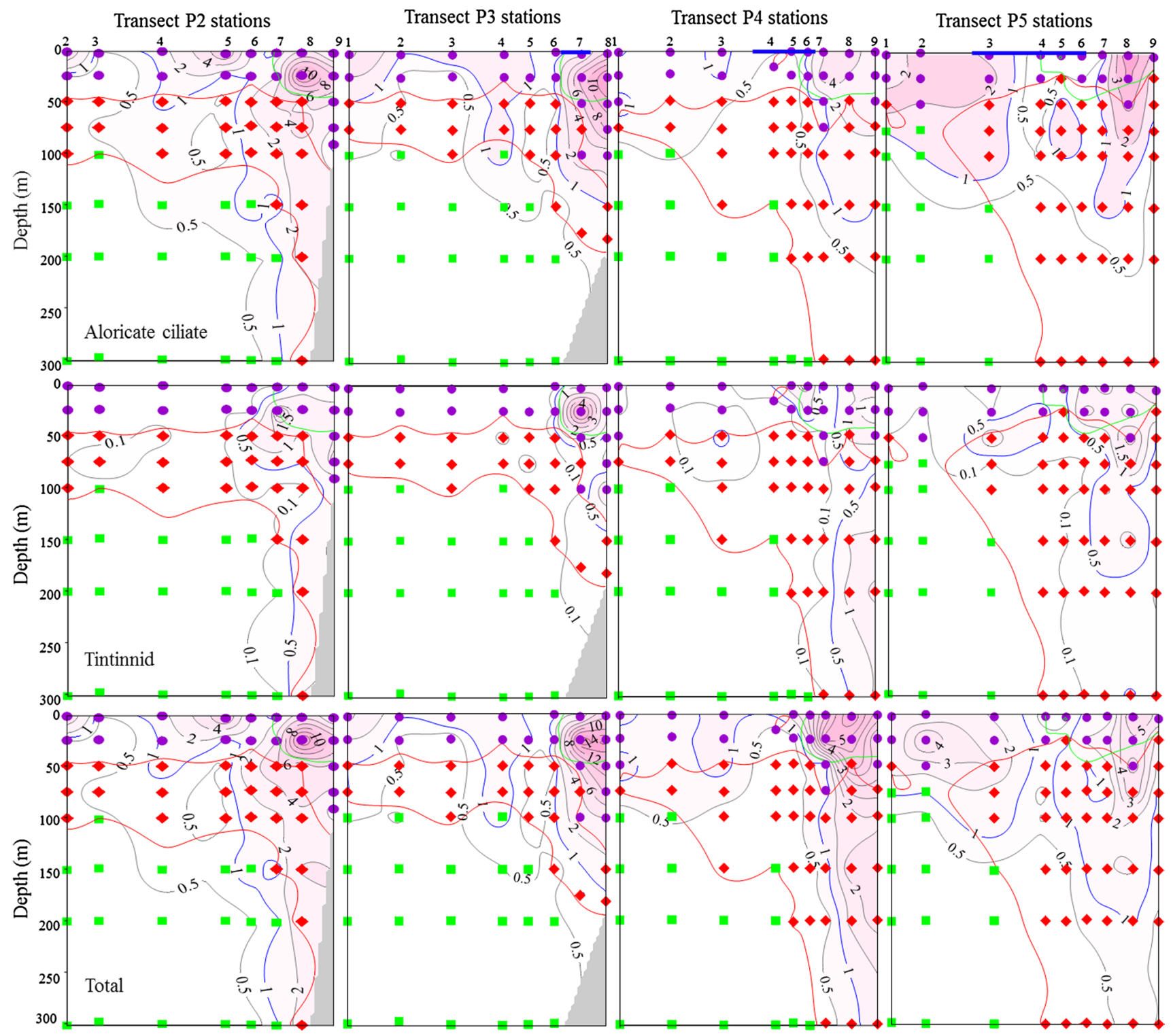

Fig. 4 Vertical distributions of biomass $\left(\mu \mathrm{g} \mathrm{C} \mathrm{L}^{-1}\right)$ of aloricate, tintinnid, and total ciliate along the transects (P2, P3, P4, P5) in open waters near Prydz Bay. Dot symbols indicate both the depths at which ciliates were sampled and the water masses where samples were col- lected (purple circle SSW; red diamond WW; green square CDW). Blue line: upwelling range at the 0-m depth. SSW: Summer Surface Water; WW: Winter Water; CDW: Circumpolar Deep Water. Red isotherm of $-1.5^{\circ} \mathrm{C}$ and green $\mathrm{Chl} a$ isoline of $3 \mathrm{mg} \mathrm{m}^{-3}$ were attached

to $1.3 \mu \mathrm{g} \mathrm{C} \mathrm{L}{ }^{-1}$ in the open water column in the Weddell Sea (Buck et al. 1992).

The proportion of tintinnid abundance to total ciliate abundance has been shown to be $<20 \%$ in oceanic waters (Suzuki and Taniguchi 1998; Gómez 2007; Sohrin et al. 2010; Yu et al. 2016). Yu et al. (2016) found that tintinnid abundance was $<10 \%$ in stations deeper than $80 \mathrm{~m}$. In the present study, the proportion of tintinnids in $\mathrm{SSW}_{\mathrm{Chl} a<3}$ (SSW, in vivo Chlorophyll $a<3 \mathrm{mg} \mathrm{m}^{-3}$ ) and WW was close to that of oceanic water. A higher tintinnid proportion was found in $\mathrm{SSW}_{\mathrm{Chl} a>3}$ than in other water masses. This phenomenon was consistent with the idea that tintinnids may be 


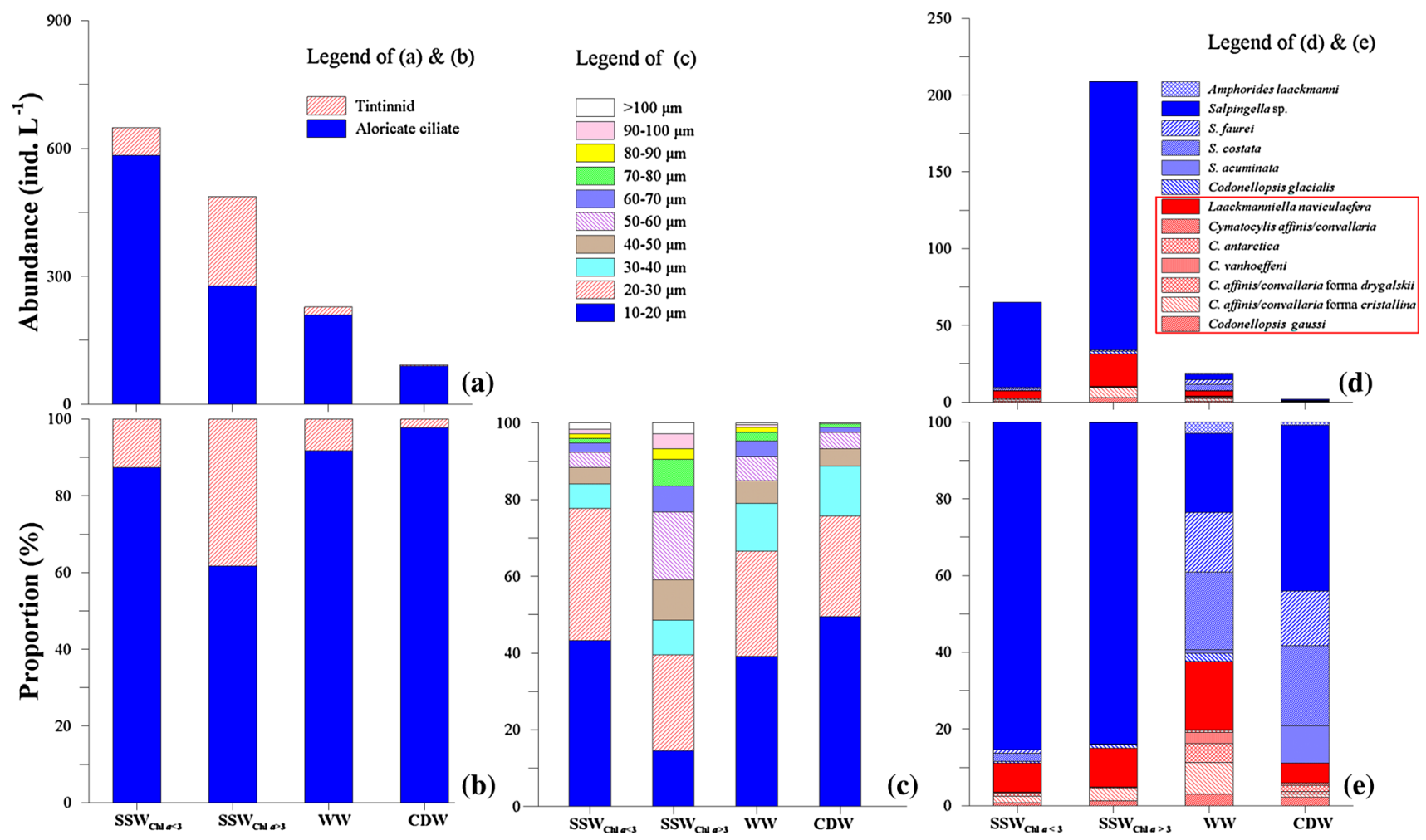

Fig. 5 Abundance of ciliate (a) and proportions of aloricate ciliate and tintinnid (b), proportions of different-sized aloricate ciliate in total aloricate ciliate abundance (c), abundances (d) and proportions (e) of different tintinnid species in different water masses. Southern

more favored than aloricate ciliates under eutrophic conditions in oceanic waters (Gómez 2007). Suzuki and Taniguchi (1998) also found that tintinnids were adapted to high Chl $a$ concentrations.

The size class of aloricate ciliates has rarely been investigated. In our study, the percentages of different size class aloricate ciliates in different layers of a low $\mathrm{Chl} a$ concentration area was roughly the same as in the tropical Western Pacific (Wang et al. 2016). However, the size class of aloricate ciliates became larger in the higher $\mathrm{Chl} a$ concentration area. There were no similar results in other studies.

\section{Tintinnid species composition}

This study was the first to investigate tintinnid species communities in open waters near Prydz Bay. A neritic assemblage has also been described in Antarctic waters (Dolan et al. 2013a). However, neritic genera (Favella, Helicostomella, Leprotintinnus, Metacylis, Stenosemella, Stylicauda, Tintinnidium, and Tintinnopsis) (Dolan et al. 2013a) were not found in the present study. These findings indicate that we did not identify the southernmost limit of the austral assemblage. The tintinnid assemblage might extend further south until it meets the neritic assemblage. However,
Ocean endemic species were in red rectangle. $\mathrm{SSW}_{\mathrm{Chl} a<3}$ : Summer Surface Water with Chl $a<3 \mathrm{mg} \mathrm{m}^{-3} ; \mathrm{SSW}_{\mathrm{Chl} a>3}$ : Summer Surface Water with Chl $a>3 \mathrm{mg} \mathrm{m}^{-3}$; WW: Winter Water; CDW: Circumpolar Deep Water

there has been only one investigation (Yu et al. 2016) of the expansion of neritic species to offshore areas. That study showed neritic species expanded from the coastal line to the 80-m (distance from bottom) isoline in the East China Sea. If this phenomenon is similar in the Antarctic, neritic species would be found in waters shallower than $80 \mathrm{~m}$. However, the shallowest depth in our study was $102 \mathrm{~m}$; therefore, it is assumed that neritic species did not occur in our study area. Thus, further studies should be conducted in nearshore areas to reveal the mixing between austral assemblage and neritic assemblages in Antarctic waters.

Dolan et al. (2012) divided tintinnid species reported from locations between $40^{\circ} \mathrm{S}$ and $78^{\circ} \mathrm{S}$ into Southern Ocean endemic species (32 species) and widespread species (161 species). In this study, we found seven Southern Ocean endemic species which was only a small part of the total endemic species list. Most endemic species did not emerge in our survey area, which was likely because their abundance was below the detection limit or they inhabited other areas of Antarctic waters. Dolan et al. (2013b) suggested that several species in the genus Cymatocylis were different morphotypes of Cymatocylis affinis/convallaria. Kim et al. (2013) classified $C$. drygalskii and C. convallaria as $C$. affinis, and $C$. gaussi as Laackmanniella (L. naviculaefera $=$ L. prolongata). 
Table 2 Tintinnid species' distribution in different water masses in open waters near Prydz Bay

\begin{tabular}{|c|c|c|c|c|c|c|c|c|c|}
\hline \multirow[t]{3}{*}{ Species } & \multicolumn{9}{|l|}{ Water masses } \\
\hline & \multicolumn{2}{|l|}{$\mathrm{SSW}_{\mathrm{Chl} a<3}$} & \multicolumn{2}{|l|}{$\mathrm{SSW}_{\mathrm{Chl} a>3}$} & \multicolumn{2}{|l|}{ WW } & \multicolumn{2}{|l|}{ CDW } & \multirow{2}{*}{$\begin{array}{l}\mathrm{PB} \\
\mathrm{OF}\end{array}$} \\
\hline & Abundance & $\mathrm{OF}$ & Abundance & OF & Abundance & OF & Abundance & OF & \\
\hline Codonellopsis gaussi & $0.53 \pm 1.78(9)$ & 7.23 & $2.76 \pm 5.06(18)$ & 9.52 & $0.58 \pm 2.75(27)$ & 4.52 & $0.05 \pm 0.37(3)$ & 2.94 & 11.36 \\
\hline C. glacialis & $0.22 \pm 0.93(6)$ & 4.82 & $1.75 \pm 5.06(24)$ & 5.95 & $0.41 \pm 2.99(32)$ & 3.01 & 0.00 & 0.00 & 7.20 \\
\hline $\begin{array}{l}\text { Cymatocylis affinis/ } \\
\text { convallaria forma } \\
\text { cristallina }\end{array}$ & $1.06 \pm 3.00(12)$ & 8.43 & $6.75 \pm 12.31(63)$ & 17.86 & $1.54 \pm 3.06(16)$ & 12.95 & $0.01 \pm 0.12$ & 2.94 & 25.00 \\
\hline C. affinis/convallaria & $0.08 \pm 0.45$ & 2.41 & $0.11 \pm 0.42(2)$ & 2.38 & $0.02 \pm 0.13(1)$ & 0.60 & $0.01 \pm 0.12(1)$ & 2.94 & 2.65 \\
\hline $\begin{array}{l}\text { C. affinis/convallaria } \\
\text { forma drygalskii }\end{array}$ & $0.45 \pm 1.43(6)$ & 6.02 & $0.41 \pm 0.94(3)$ & 5.95 & $0.92 \pm 1.92(10)$ & 9.94 & $0.01 \pm 0.12$ & 2.94 & 16.67 \\
\hline C. vanhoeffeni & $0.20 \pm 1.40(10)$ & 1.20 & $0.30 \pm 1.55(8)$ & 1.19 & $0.55 \pm 1.42(8)$ & 7.23 & 0.00 & 0.00 & 9.85 \\
\hline C. antarctica & 0.00 & 0.00 & 0.00 & 0.00 & $0.11 \pm 0.69(6)$ & 1.20 & $0.03 \pm 0.24(2)$ & 2.94 & 1.89 \\
\hline $\begin{array}{l}\text { Laackmanniella } \\
\text { naviculaefera }\end{array}$ & $4.97 \pm 13.00(72)$ & 16.87 & $21.17 \pm 28.88$ & 25.00 & $3.34 \pm 5.35(32)$ & 19.58 & $0.10 \pm 0.55$ & 8.82 & 39.02 \\
\hline Salpingella acuminata & 0.00 & 0.00 & 0.00 & 0.00 & $0.17 \pm 0.73(6)$ & 3.01 & $0.19 \pm 0.74$ & 17.65 & 6.06 \\
\hline S. costata & $1.43 \pm 8.99(64)$ & 3.61 & 0.00 & 0.00 & $3.81 \pm 18.71(201)$ & 13.55 & $0.42 \pm 1.69(10)$ & 20.59 & 20.83 \\
\hline S. faurei & $0.59 \pm 2.42(16)$ & 6.02 & $0.45 \pm 1.83(9)$ & 2.38 & $2.91 \pm 9.99(79)$ & 10.54 & $0.29 \pm 1.88(15)$ & 11.76 & 17.42 \\
\hline Salpingella sp. & $55.51 \pm 80.26(346)$ & 43.37 & $\begin{array}{l}174.98 \pm 255.15 \\
\quad(1014)\end{array}$ & 28.57 & $3.88 \pm 11.30(91)$ & 12.05 & $0.87 \pm 4.58(36)$ & 23.53 & 40.91 \\
\hline $\begin{array}{l}\text { Amphorides laack- } \\
\text { manni }\end{array}$ & 0.00 & 0.00 & $0.34 \pm 0.87(5)$ & 1.19 & $0.55 \pm 3.61(33)$ & 1.81 & $0.01 \pm 0.12(1)$ & 2.94 & 3.03 \\
\hline
\end{tabular}

In each water mass are displayed the average abundance \pm SE (ind. $\mathrm{L}^{-1}$ ) of each tintinnid species with its maximum value (ind. $\mathrm{L}^{-1}$ ) in parenthesis as well as its occurrence frequency $(\%)$

$O F$ occurrence frequency of each tintinnid species calculated by dividing the total number of sampling points by the number of sampling points where this species occurred, $S S W_{C h l a<3}$ Summer Surface Water with Chl $a<3 \mathrm{mg} \mathrm{m}^{-3}$, sampling points $n=51, S S W_{C h l a>3}$ Summer Surface Water with Chl $a>3 \mathrm{mg} \mathrm{m}^{-3}$, sampling points $n=27, W W$ Winter Water, sampling points $n=119$, $C D W$ Circumpolar Deep Water, sampling points $n=67, P B$ Prydz Bay, sampling points $n=264$

Therefore, we considered C. drygalskii, C. cristallina and C. convallaria to be polymorphic forms and combined them under the name $C$. affinis/convallaria. However, this was not done for $C$. antarctica and $C$. vanhoeffeni because of their very different morphotypes. In addition, $L$. naviculaefera and $C$. gaussi were treated as different species because they showed distinct morphologies in our study.

In this study, C. affinis/convallaria forma cristallina was the dominant morphotype, and C. affinis/convallaria forma affinis and convallaria occurred occasionally in Prydz Bay. However, C. affinis/convallaria forma convallaria was dominant in Admiralty Bay (King George Island) in austral summer, occupying up to $90 \%$ of the total tintinnid proportion, while $C$. affinis/convallaria forma cristallina did not appear (Wasik and Mikolajczy 1994). This distinct difference might reflect geographic differences of tintinnid occurrence.

In the present study, Salpingella sp. was the most abundant species, which was consistent with the results of previous studies. For instance, the maximum abundance of Salpingella sp. reached 1300 ind. $\mathrm{L}^{-1}$ at a nearshore site in Signy Island (Leakey et al. 1994) and 380 ind. $\mathrm{L}^{-1}$ in the ice-edge zone of the Weddell Sea (Buck et al.1992).
Based on pictures and the size of lorica observed in previous studies (Heinbokel and Coats 1985; Buck et al. 1992), the Salpingella sp. observed in the present study may be the same as that of Salpingella sp. \#1 observed in the Weddell Sea (Buck et al. 1992).

All Southern Ocean endemic tintinnid species except for $C$. gaussi were limited to the onshore side of the transects from $65^{\circ} \mathrm{S}$ to $67.51^{\circ} \mathrm{S}$ in the present study. Similarly, C. affinis/convallaria forma drygalskii was defined as most abundant in the ice-covered coastal zone in the Bellingshausen Sea (Alder and Boltovskoy 1991), while it was dominant in the Amundsen Sea, where it tended to be distributed near the shore (Jiang et al. 2014). In another study, C. affinis/convallaria forma drygalskii was almost entirely restricted to the region between $74^{\circ} \mathrm{S}$ and the Filchner Iceshelf (Boltovskoy et al. 1989).

\section{Indigenous tintinnid species in water masses determined their vertical distribution}

Because some tintinnid species had higher abundance in a certain water mass than in other water masses, we took them 

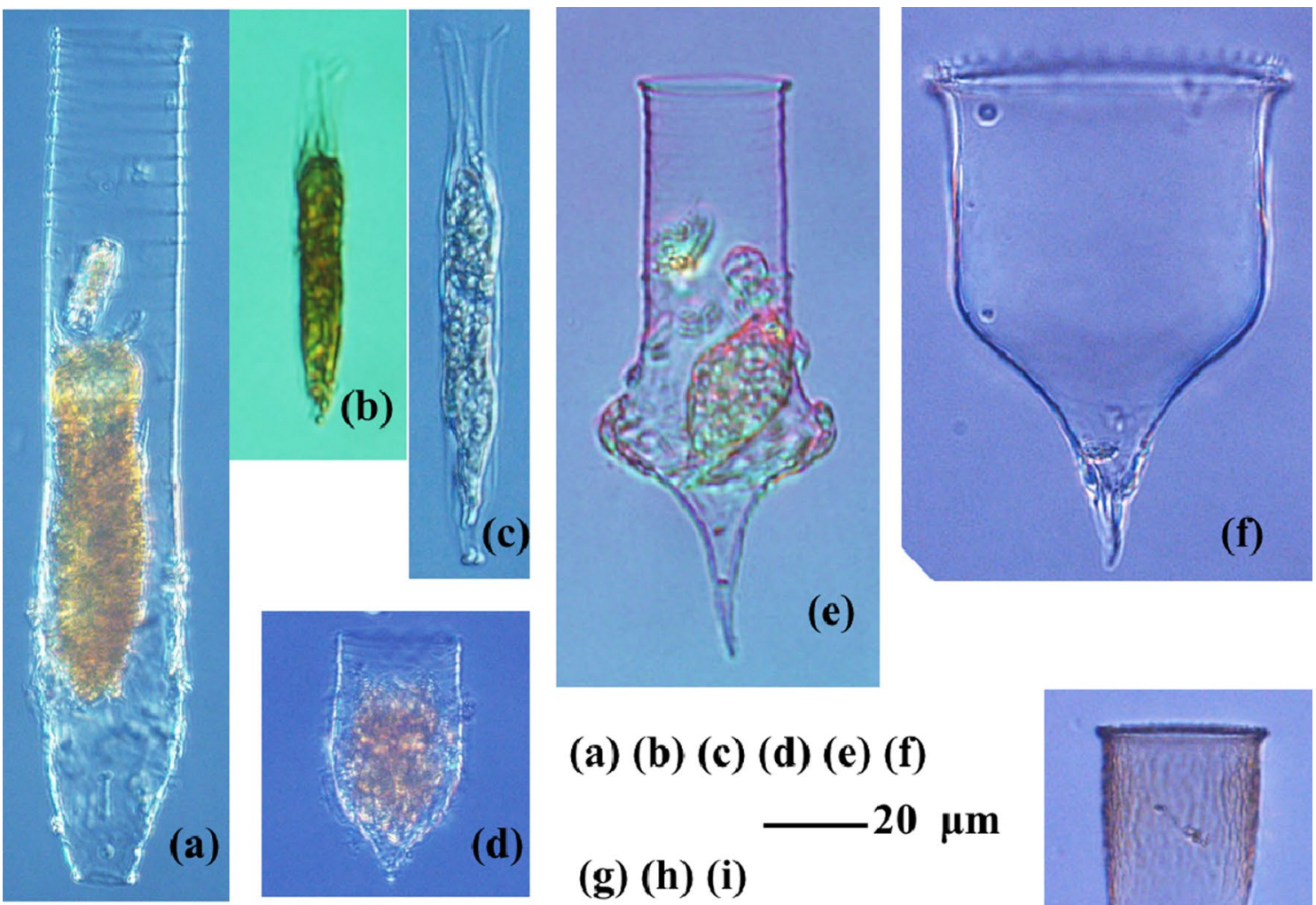

(e)

(a) (b) (c) (d) (e) (f)
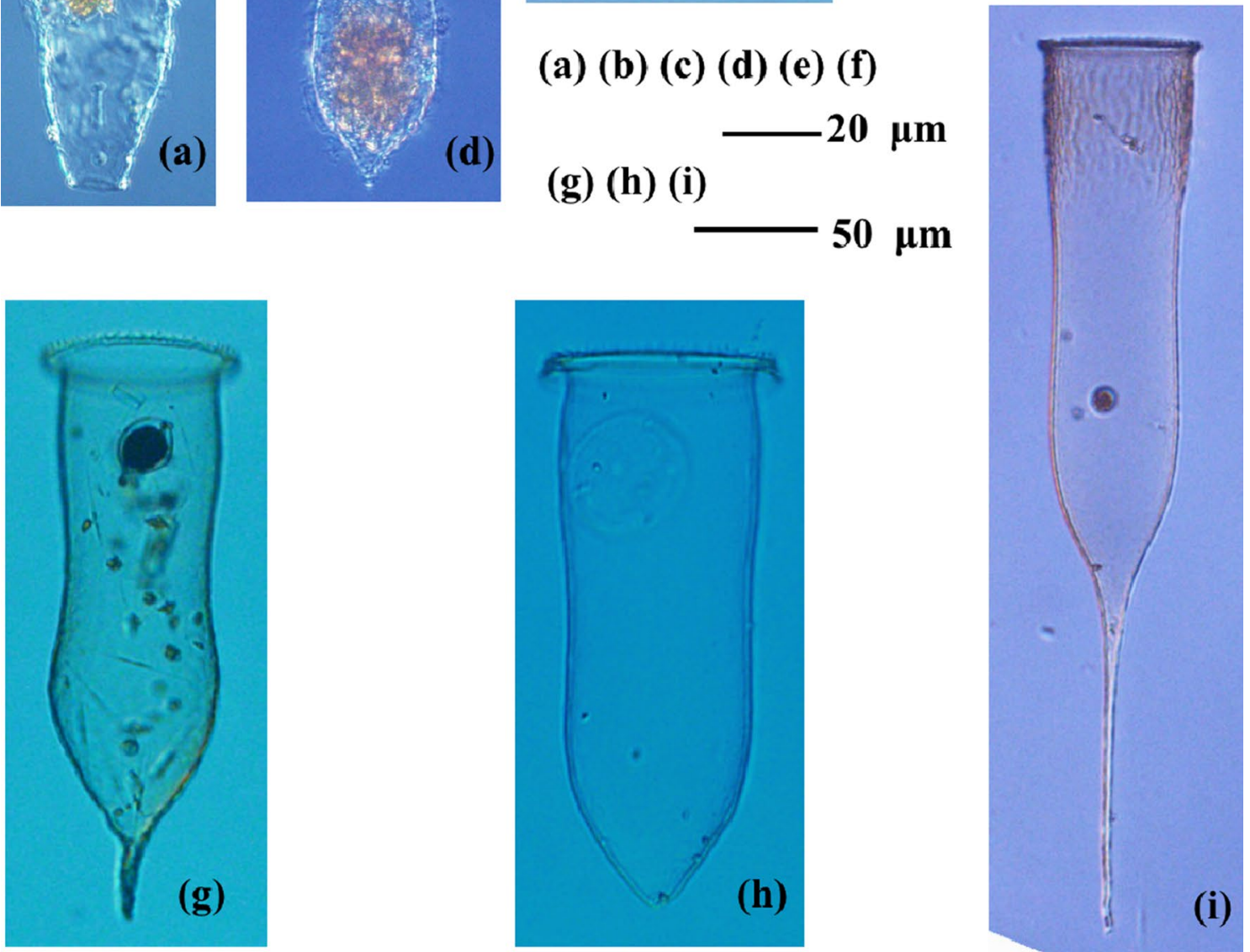

Fig. 6 Photos of some tintinnid species in open waters near Prydz Bay. a Laackmanniella naviculaefera, b Salpingella sp., c S. faurei, d Codonellopsis glacialis, e C. gaussi, f Cymatocylis affinis/conval-

to be indigenous species of this water mass. All the indigenous species form indigenous assemblages of this certain water mass. In this study, SSW indigenous assemblage was composed of Salpingella sp. and C. gaussi, WW indigenous laria, g C. affinis/convallaria forma drygalskii, h C. affinis/convallaria forma cristallina, i C. vanhoeffeni

assemblage included S. costata, S. faurei, C. affinis/convallaria forma drygalskii and $C$. vanhoeffeni, and there was no indigenous assemblage in CDW. The tintinnid assemblage in one certain water mass was a mixture of indigenous 


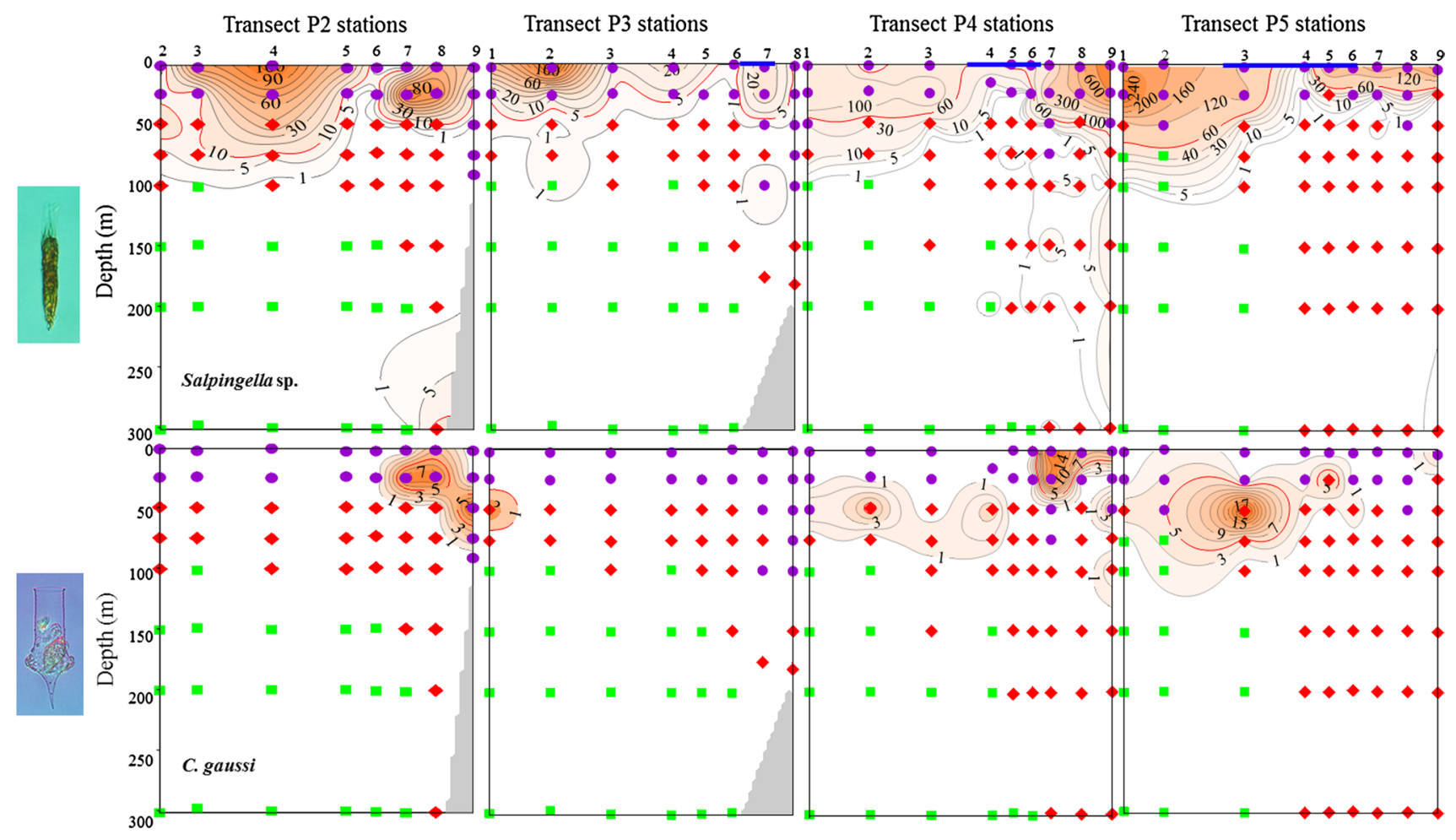

Fig. 7 Vertical distribution of abundance (ind. $\mathrm{L}^{-1}$ ) of tintinnid species (Pattern 1) in open waters near Prydz Bay. Dot symbols indicate both the depth at which ciliates were sampled and the water masses where samples were collected (purple circle SSW; red diamond WW;

tintinnids of this water mass and those indigenous to other water masses in addition to some occasional species. Our results supported the hypothesis that different ciliates have different preferred water masses.

Although previous studies of tintinnids in Antarctic waters did not define any tintinnid species-water mass relationship, some studies have investigated their vertical distribution (e.g., Boltovskoy and Alder 1992; Kivi and Kuosa 1994; Christaki et al. 2008). Since water masses were vertically divided in our study area, we were able to compare our results with these previous studies. In our study, Salpingella sp. and C. gaussi mainly inhabited SSW, which was consistent with the results of previous studies that showed they were present in higher abundance in surface waters. For example, the abundance of Salpingella sp. was higher in the upper $50 \mathrm{~m}$ than in deeper waters in the ice-edge zone of the Weddell Sea (Buck et al. 1992). C. gaussi (maximum 40.3 ind. $\mathrm{L}^{-1}$ ) mainly existed in the upper $50 \mathrm{~m}$ of the ice-edge zone in the Weddell Sea (Boltovskoy and Alder 1992).

Four species ( $S$. fauri, S. costata, C. affinis/convallaria forma drygalskii and $C$. vanhoeffeni) were mainly found in WW in this study. No specific vertical distribution pattern of these species was reported in previous studies. green square CDW). Blue line: upwelling range at the 0-m depth. SSW: Summer Surface Water; WW: Winter Water; CDW: Circumpolar Deep Water. Tintinnid pictures were attached

Boltovskoy and Alder (1992) reported that Salpingella sp. was mainly distributed in deep water $(>100 \mathrm{~m})$ in the Weddell Sea. This species distribution pattern was similar to that of $S$. fauri and $S$. costata observed in the present study. Because there was no concrete species information about Salpingella sp. reported in Boltovskoy and Alder (1992), we suggest that the Salpingella sp. observed in their study might be the $S$. fauri or $S$. costata found in the present study.

In the present study, C. affinis/convallaria forma cristallina and L. naviculaefera were found in high abundance in $\mathrm{SSW}_{\mathrm{Chl} a>3}$ and WW. L. naviculaefera is a surface species for which the maximum abundance (131 ind. $\mathrm{L}^{-1}$ ) was observed at $25 \mathrm{~m}$ in our study. This species has previously been reported to be present in maximum abundance (40.2 ind. $\mathrm{L}^{-1}$ ) at $50 \mathrm{~m}$ in the Weddell Sea (Boltovskoy and Alder 1992). To the best of our knowledge, there is no vertical distribution data for C. affinis/convallaria forma cristallina in the available literature. Other species like A. laackmanni and $C$. antarctic with no concrete pattern were rare in our study and we did not find any previous distribution data regarding these species. 


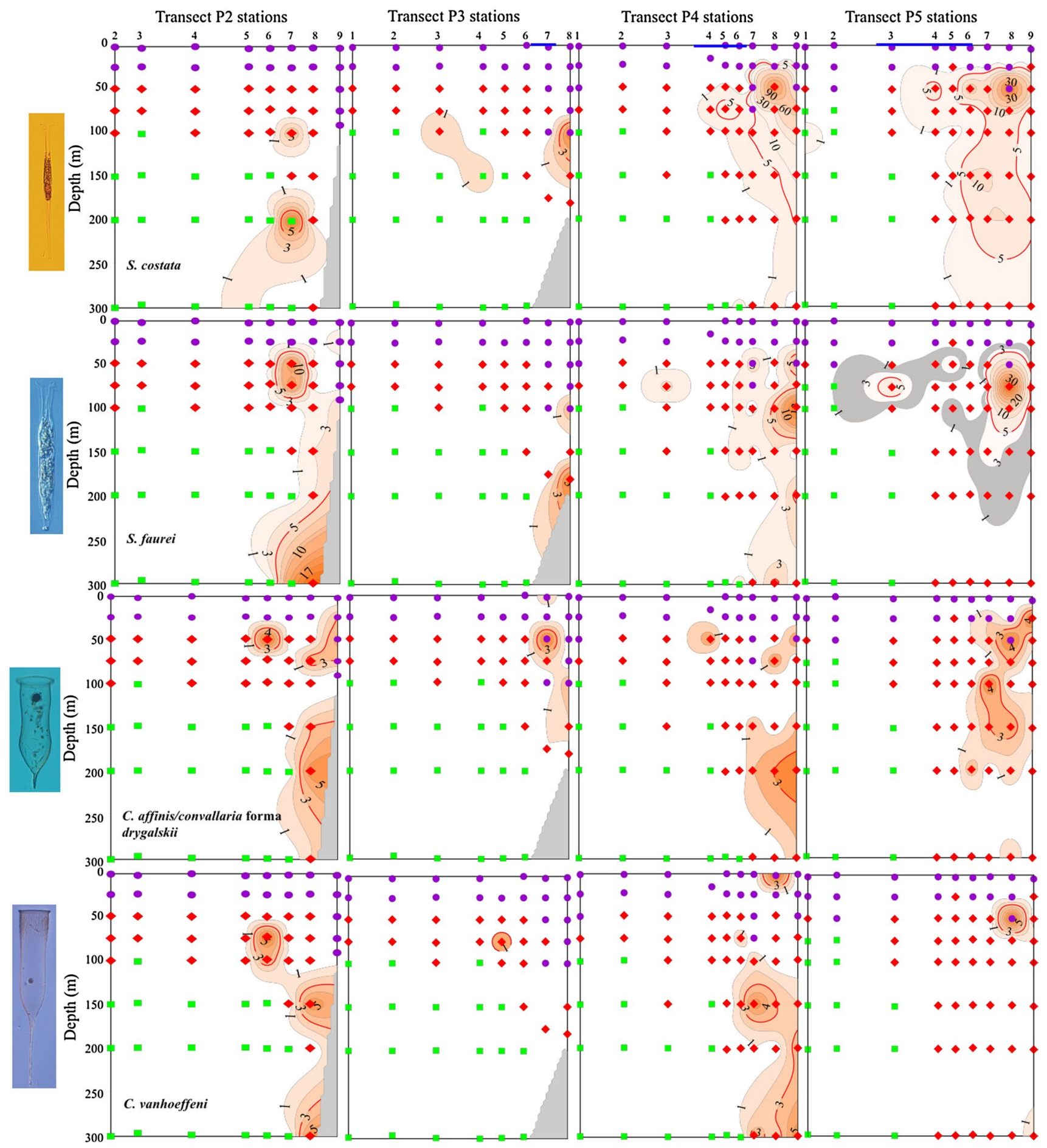

Fig. 8 Vertical distribution of abundance (ind. $\mathrm{L}^{-1}$ ) of tintinnid species (Pattern 2) in open waters near Prydz Bay. Dot symbols indicate both the depth at which ciliates were sampled and the water masses where samples were collected (purple circle SSW; red diamond WW;

\section{Influences of upwelling on ciliate distribution}

Another characteristic of the distribution pattern is the influence of upwelling. Although this upwelling has long been green square CDW). Blue line: upwelling range at the 0-m depth. SSW: Summer Surface Water; WW: Winter Water; CDW: Circumpolar Deep Water. Tintinnid pictures were attached

recognized (Middleton and Humphries 1989), its influence on plankton distribution has not been investigated to date. The combined effects of the coast and upwelling could be responsible for Chl $a$ intensification in surface waters at 


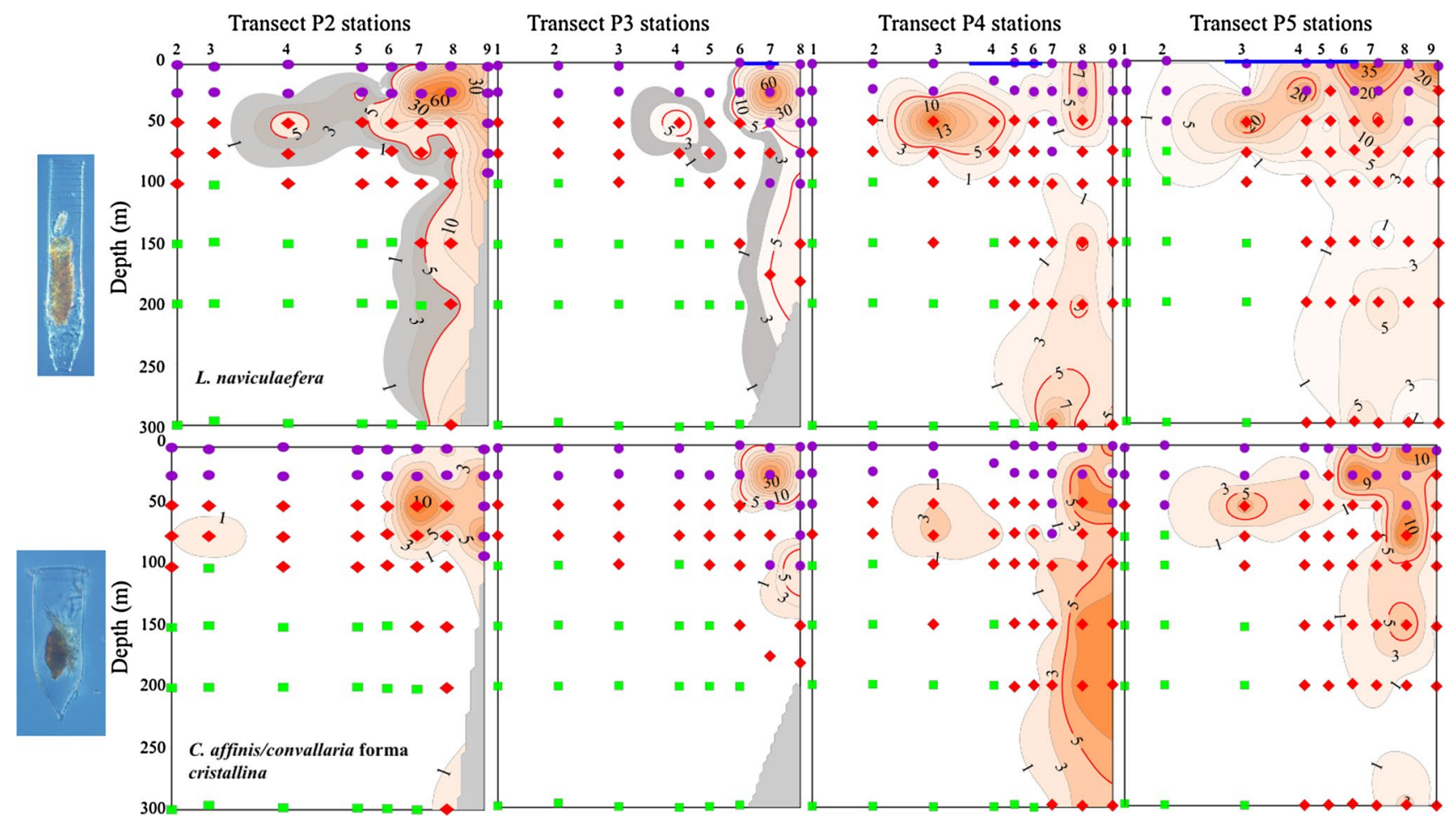

Fig. 9 Vertical distribution of abundance (ind. $\mathrm{L}^{-1}$ ) of tintinnid species (Pattern 3) in open waters near Prydz Bay. Dot symbols indicate both the depth at which ciliates were sampled and the water masses where samples were collected (purple circle SSW; red diamond WW; green square $\mathrm{CDW}$ ). Blue line: upwelling range at the 0-m depth. SSW: Summer Surface Water; WW: Winter Water; CDW: Circumpolar Deep Water. Tintinnid pictures were attached the coastal ends of the transects. Upwelling occurred in the same location in which low abundance of surface ciliates and some tintinnid species occurred. Because deep water had low ciliate abundance, we propose that this upwelling was responsible for the low abundance areas. L. naviculaefera and C. affinis/convallaria forma cristallina occurred in WW, and were the most abundant Southern Ocean endemic species in WW. Therefore, these two species might be more adaptive than other endemic species in WW. We speculate that these two species might be the original inhabitants in WW. When WW was brought to the surface by upwelling, these two species were able to survive and prosper, while others perished. Because the upwelling moved both upward and coastward, these two species occurred in $\mathrm{SSW}_{\mathrm{Chl} a>3}$ but not in $\mathrm{SSW}_{\mathrm{Chl} a<3}$.

Upwelling in Prydz Bay is a part of the "Antarctic divergence" which generally occurs at $60^{\circ} \mathrm{S}-65^{\circ} \mathrm{S}$, although it shows great variations with time (Mann and Lazier 2006; Lin et al. 2016). Thus, the influence of upwelling on ciliate distribution in our study might have occurred in other Antarctic waters in which upwelling was found.

\section{Prediction of spatial and temporal variations of austral tintinnid assemblage}

Because different water masses inhabited different indigenous assemblages, we predicted tintinnid assemblages in other areas and times according to the spatial and temporal variations of water masses in the Southern Ocean. The sandwich structures of SSW, WW, and CDW stretched from waters near Prydz Bay northward until Antarctic Circumpolar Current (ACC) mixed the water layers. Therefore, we speculate that the distributions of austral tintinnid assemblages were similar in waters from our study area to those of ACC.

According to data recorded at the Chinese Antarctic Station of Zhongshan, air temperature was the highest in January (http://polar.chinare.gov.cn/meteo/). Our study was conducted at the end of austral summer, when WW was at its minimum range. As time went on, SSW gradually disappeared and was replaced by WW; thus, WW occupied more of the surface water. Therefore, in winter, the abundance of the dominant species, Salpingella sp. 


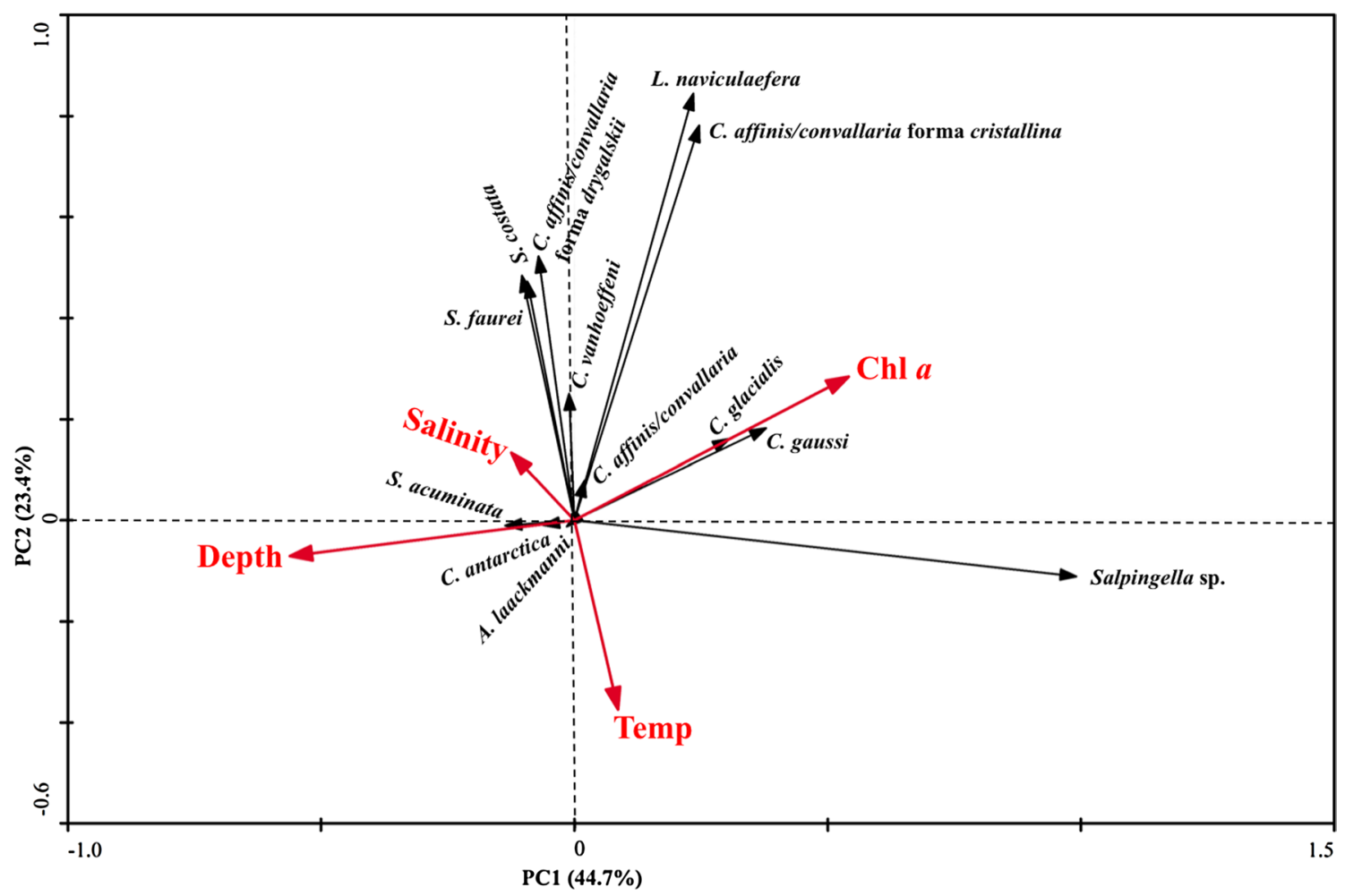

Fig. 10 Principal component analysis (PCA) of tintinnid ciliate abundance and different seawater samples associated with environmental variables. The $x$-axis is the first PCA axis, and the $y$-axis is the sec-

(which was indigenous in SSW), will decrease. Tintinnid species indigenous in WW might move northward and upward to the surface waters, resulting in the increase of their proportion.

We do not have species information regarding aloricate ciliates; however, the aloricate assemblage might utilize the same mechanism as tintinnid species because of their close phylogenetic relationship. Although there have been no reports on other plankton differences in different water masses in the Antarctic, this mechanism might also exist in phytoplankton and zooplankton.

In summary, the results of this study supported our hypothesis that different water masses had ciliate assemblages with different characteristics and indigenous tintinnids. Tintinnid vertical distribution could be determined by whether they were indigenous to water masses. Our results will help predict the spatial and temporal variations in assemblages of ciliates and other plankton according to the dynamics of water masses in Antarctic waters.

Acknowledgements We thank the 31st CHINARE Antarctic expedition for providing logistical support and environmental data. We thank Jeremy Kamen, MSc, from Liwen Bianji, Edanz Group China (www. liwenbianji.cn/ac), for editing the English text of a previous version of this manuscript. This study was supported by the National Natural ond PCA axis. Environmental variables and tintinnid species are indicated by red arrows and black arrows, respectively

Science Foundation of China (NSFC 41576164); Chinese Polar Environment Comprehensive Investigation \& Assessment Programmes (CHINARE2015-01-06 and CHINARE2015-01-05); the Scientific and Technological Innovation Project by Qingdao National Laboratory for Marine Science and Technology (No. 2015ASKJ02); and the CNRS-NSFC Joint Research Projects Program (NSFC 41711530149).

\section{Compliance with ethical standards}

Conflict of interest The authors declare that they have no conflicts of interest.

Ethical standards All procedures involving animals were performed in accordance with the ethical standards of the institutions at which the studies were conducted

\section{References}

Alder VA (1999) Tintinnoinea. In: Boltovskoy D (ed) South Atlantic zooplankton. Backhuys, Leiden, pp 321-384

Alder VA, Boltovskoy D (1991) Microplanktonic distribution patterns west of the Antarctic Peninsula, with special emphasis on the tintinnids. Polar Biol 11:103-112

Angel MV (1993) Biodiversity of the pelagic ocean. Conserv Biol 7:760-772 
Azam F, Fenchel T, Field JG, Gray JS, Meyer-Reil LA, Thingstad F (1983) The ecological role of water column microbes in the sea. Mar Ecol Prog Ser 10:257-263

Beers JR (1967) The species distribution of some naturally-occurring quaternary ammonium compounds. Comp Biochem Physiol 21:11-21

Bernard C, Rassoulzadegan F (1993) The role of picoplankton (cyanobacteria and plastidic picoflagellates) in the diet of tintinnids. J Plankton Res 15:361-373

Boltovskoy D, Alder VA (1992) Microzooplankton and tintinnid species-specific assemblage structures: patterns of distribution and year-to-year variations in the Weddell Sea (Antarctica). J Plankton Res 14:212-217

Boltovskoy D, Alder VA, Spinelli F (1989) Summer Weddell sea microplankton: assemblage structure, distribution and abundance, with special emphasis on the Tintinnina. Polar Biol 9:447-456

Boltovskoy D, Dinofrio EO, Alder VA (1990) Intraspecific variability in Antarctic tintinnids: the Cymatocylis affinis/convallaria species group. J Plankton Res 12:403-413

Buck KR, Garrison DL, Hopkins TL (1992) Abundance and distribution of tintinnid ciliates in an ice edge zone during the austral autumn. Antarct Sci 4:3-8

Capriulo GM (1983) Abundance, species composition and feeding impact of tintinnid micro-zooplankton in central Long Island Sound. Mar Ecol Prog Ser 10:277-288

Christaki U, Obernosterer I, Wambeke FV, Veldhuis M, Garcia N, Catala P (2008) Microbial food web structure in a naturally ironfertilized area in the Southern Ocean (Kerguelen Plateau). Deep Sea Res Part II 55:706-719

Davidson AT, Marchant HJ (1992) Protist abundance and carbon concentration during a Phaeocystis-dominated bloom at an Antarctic coastal site. Polar Biol 12:387-395

Dolan JR, Yang EJ (2017) Observations of apparent lorica variability in Salpingacantha (Ciliophora: Tintinnida) in the Northern Pacific and Arctic Oceans. Acta Protozool 56:221-224

Dolan JR, Pierce RW, Yang EJ, Kim SY (2012) Southern Ocean biogeography of tintinnid ciliates of the marine plankton. J Eukaryot Microbiol 59:511-519

Dolan JR, Montagnes DJ, Agatha S, Coats DW, Stoecker DK (2013a) The biology and ecology of tintinnid ciliates: models for marine plankton. Wiley, Oxford

Dolan JR, Yang EJ, Lee SH, Kim SY (2013b) Tintinnid ciliates of the Amundsen Sea (Antarctica) plankton communities. Polar Res 32:19784

Gao G, Dong Z, Shi M, Liu H (2013) Advances of oceanographic study on Prydz Bay and adjacent region, Antarctica. J Shanghai Ocean Univ 22:313-320

Garrison DL, Buck KR (1989) Protozooplankton in the Weddell Sea, Antarctica: abundance and distribution in the ice-edge zone. Polar Biol 9:341-351

Garrison DL, Buck KR, Gowing MM (1991) Plankton assemblages in the ice edge zone of the Weddell Sea during the austral winter. J Mar Syst 2:123-130

Gómez F (2007) Trends on the distribution of ciliates in the open Pacific Ocean. Acta Oecol 32:188-202

Gowing MM, Garrison DL (1992) Abundance and feeding ecology of larger protozooplankton in the ice edge zone of the Weddell and Scotia Seas during the austral winter. Deep Sea Res A 39:893-919

Hada Y (1970) The protozoan plankton of the Antarctic and subantarctic seas. Sci Rep Ser E 31:1-51

Heinbokel JF, Beers JR (1979) Studies on the functional role of tintinnids in the Southern California Bight. III. Grazing impact of natural assemblages. Mar Biol 52:23-32
Heinbokel JF, Coats DW (1985) Ciliates and nanoplankton in Arthur Harbor, December 1984 and January 1985. Antarct J US 19:135-136

Heinbokel JF, Coats DW (1986) Patterns of tintinnina abundance and reproduction near the edge of seasonal pack-ice in the Weddell Sea, November 1983. Mar Ecol 33:71-80

Jiang Y, Yang EJ, Kim SY, Kim YN, Lee SH (2014) Spatial patterns in pelagic ciliate community responses to various habitats in the Amundsen Sea (Antarctica). Prog Oceanogr 128:49-59

Jiang Y, Liu Q, Yang EJ, Wang M, Kim TW, Cho KH, Lee SH (2015) Pelagic ciliate communities within the Amundsen Sea polynya and adjacent sea ice zone, Antarctica. Deep Sea Res Part II 123:69-77

Jiang Y, Liu Q, Yang EJ, Wang M, Li Y, Lee SH (2016) An approach to bioassess pelagic ciliate biodiversity at different taxonomic resolutions in response to various habitats in the Amundsen Sea (Antarctica). Polar Biol 39:485-495

Kato S, Taniguchi A (1993) Tintinnid ciliates as indicator species of different water masses in the western North Pacific Polar Front. Fish Oceanogr 2:166-174

Kim SY, Choi JK, Dolan JR, Shin HC, Lee SH, Yang EJ (2013) Morphological and ribosomal DNA-based characterization of six Antarctic ciliate morphospecies from the Amundsen Sea with phylogenetic analyses. J Eukaryot Microbiol 60:497-513

Kivi K, Kuosa H (1994) Late winter microbial communities in the western Weddell Sea (Antarctica). Polar Biol 14:389-399

Kobari T, Moku M, Takahashi K (2008) Seasonal appearance of expatriated boreal copepods in the Oyashio-Kuroshio mixed region. ICES J Mar Sci 65:469-476

Kofoid CA, Campbell AS (1929) A conspectus of the marine and fresh-water Ciliata belonging to the suborder Tintinnoinea, with description of the suborder Tintinnoinea, with description of new species principally from Agassiz Expedition to the Eastern Tropical Pacific, 1904-1905. Univ Calif Publ Zool 34:1-403

Kofoid CA, Campbell AS (1939) The Ciliata: the Tintinnoinea. Bull Mus Comp Zool Harv Coll 84:1-473

Laackmann H (1910) Die Tintinnodeen der deutschen Südpolar-Expedition 1901-1903. Dtsch Stüdpol Exped 2:341-496

Laval-peuto M, Heinbokel JF, Anderson OR (1986) Role of microand nanozooplankton in marine food webs. Int J Trop Insect Sci 7:387-395

Le K, Shi J, Yu K (1996) An analysis on water masses and thermohaline structures in the region of Prydz Bay, Antarctica. Chin J Oceanol Limnol 27:229-236 (in Chinese with English abstract)

Leakey RJG, Fenton N, Clarke A (1994) The annual cycle of planktonic ciliates in nearshore waters at Signy Island, Antarctica. J Plankton Res 16:841-856

Li H, Xu Z, Zhang W, Wang S, Zhang G, Xiao T (2016) Boreal tintinnid assemblage in the Northwest Pacific and its connection with the Japan Sea in Summer 2014. PLoS ONE 11:e0153379

Liang Y, Bai X, Jiang Y, Wang M, He J, McMinn A (2016) Distribution of marine viruses and their potential hosts in Prydz Bay and adjacent Southern Ocean, Antarctic. Polar Biol 39:365-378

Lin L, Chen H, Liu N (2016) An analysis on the upwelling of the modified circumpolar deep water over the shelf region of Prydz Bay in the summer of 2013. Acta Oceanol Sin 38:46-55 (in Chinese with English abstract)

Longhurst AR (2007) Ecological geography of the sea, 2nd edn. Academic Press, New York

Lynn DH (2008) Ciliated protozoa: characterization, classification, and guide to the literature, 3rd edn. Springer, Berlin, pp 1-455

Mann KH, Lazier JRN (2006) Dynamics of marine ecosystems: biological-physical interactions in the oceans, 3rd edn. Blackwell, London, pp 106-107 
Middleton JH, Humphries SE (1989) Thermohaline structure and mixing in the region of Prydz Bay, Antarctica. Deep Sea Res A 36:1255-1266

Mura MP, Satta MP, Agustí S (1995) Water-mass influences on summer Antarctic phytoplankton biomass and community structure. Polar Biol 15:15-20

Paranjape MA, Gold K (1982) Cultivation of marine pelagic protozoa. Ann Inst Oceanogr Paris 58:143-150

Paterson H, Laybourn-Parry J (2012) Sea ice microbial dynamics over an annual ice cycle in Prydz Bay, Antarctica. Polar Biol 35:993-1002

Pierce RW, Turner JT (1992) Ecology of planktonic ciliates in marine food webs. Rev Aquat Sci 6:139-181

Pierce RW, Turner JT (1993) Global biogeography of marine tintinnids. Mar Ecol Prog Ser 94:11-26

Pierce RW, Turner JT (1994) Plankton studies in Buzzards Bay, Massachusetts, USA, IV. Tintinnids, 1987-1988. Mar Ecol Prog Ser 112:235-240

Priede IG (2014) Biogeography of the oceans: a review of development of knowledge of currents, fronts and regional boundaries from sailing ships in the sixteenth century to satellite remote sensing. Pure Appl Geophys 171:1013-1027

Putt M, Stoecker DK (1989) An experimentally determined carbon: volume ratio for marine "Oligotrichous" ciliates from estuarine and coastal waters. Limnol Oceanogr 34:407-416

Shi J, Dong Z, Chen H (2013) Progress of Chinese research in physical oceanography of the Southern Ocean. Adv Polar Sci 24:86-97

Smith NR, Dong Z, Kerry KR, Wright S (1984) Water masses and circulation in the region of Prydz Bay, Antarctica. Deep Sea Res A 31:1121-1147

Sohrin R, Imazawa M, Fukuda H, Suzuki Y (2010) Full-depth profiles of prokaryotes, heterotrophic nanoflagellates, and ciliates along a transect from the equatorial to the subarctic central Pacific Ocean. Deep Sea Res Part II 57:1537-1550

Stoecker DK, Buck KR, Putt M (1992) Changes in the sea-ice brine community during the spring-summer transition, McMurdo Sound, Antarctica. I. Photosynthetic protist. Mar Ecol Prog Ser $84: 265-278$

Suzuki T, Taniguchi A (1998) Standing crops and vertical distribution of four groups of marine planktonic ciliates in relation to phytoplankton chlorophyll $a$. Mar Biol 132:375-382

Thomson PG, Davidson AT, Van den Enden R, Pearce I, Seuront L, Paterson JS, Williams GD (2010) Distribution and abundance of marine microbes in the Southern Ocean between 30 and $80 \mathrm{E}$. Deep Sea Res Part II 57:815-827
Tomczak M, Godfrey JS (1994) Regional oceanography: an introduction, 1st edn. Pergamon, New York

Vaz RAN, Lennon GW (1996) Physical oceanography of the Prydz Bay region of Antarctic waters. Deep-Sea Res A 43:603-641

Verity PG (1987) Abundance, community composition, size distribution, and production rates of tintinnids in Narragansett Bay, Rhode Island. Est Coast Shelf Sci 24:671-690

Verity PG, Langdon C (1984) Relationships between lorica volume, carbon, nitrogen, and ATP content of tintinnids in Narragansett Bay. J Plankton Res 6:859-868

Wang C, Zhao L, Zhao Y, Li H, Chen X, Zhang S, Zhang W, Xiao $\mathrm{T}$ (2016) Vertical distribution of planktonic ciliates in tropical Western Pacific. Oceanol Limnol Sin 47:429-437 (in Chinese with English abstract)

Wasik A, Mikolajczy E (1994) Annual cycle of tintinnids in Admiralty Bay with an emphasis on seasonal variability in Cymatocylis affinis/convallaria lorica morphology. J Plankton Res 16:1-8

Waters RL, van den Enden R, Marchant HJ (2000) Summer microbial ecology off East Antarctica $\left(80-150^{\circ} \mathrm{E}\right)$ : protistan community structure and bacterial abundance. Deep Sea Res Part II 47:2401-2435

Wickham SA, Steinmair U, Kamennaya NA (2011) Ciliate distributions and forcing factors in the Amundsen and Bellingshausen Seas (Antarctic). Aquat Microb Ecol 62:215-230

Williams G, Aoki S, Jacobs S, Rintoul S, Tamura T, Bindoff N (2010) Antarctic bottom water from the Adélie and George V Land coast, East Antarctica (140-149 ${ }^{\circ}$ E). J Geohys Res D. https://doi. org/10.1029/2009jc005812

Yu Y, Zhang W, Feng M, Zhao Y, Zhang C, Zhou F, Xiao T (2016) Differences in the vertical distribution and response to freshwater discharge between aloricate ciliates and tintinnids in the East China Sea. J Mar Syst 154:103-109

Zhang F, Ma Y, Lin L, He J (2012a) Hydrophysical correlation and water mass indication of optical physiological parameters of picophytoplankton in Prydz Bay during autumn 2008. J Microbiol Methods 91:559-565

Zhang W, Feng M, Yu Y, Zhang C, Xiao T (2012b) An illustrated guide to contemporary tintinnids in the world. Science Press, Beijing

Zhu G, Liu Z, Ning X, Wang M (1994) Distribution characteristics of planktonic nano and microalgae in the Prydz Bay and its adjacent Southern Indian Ocean, during austral summer. Adv Polar Sci $5: 33-44$ 


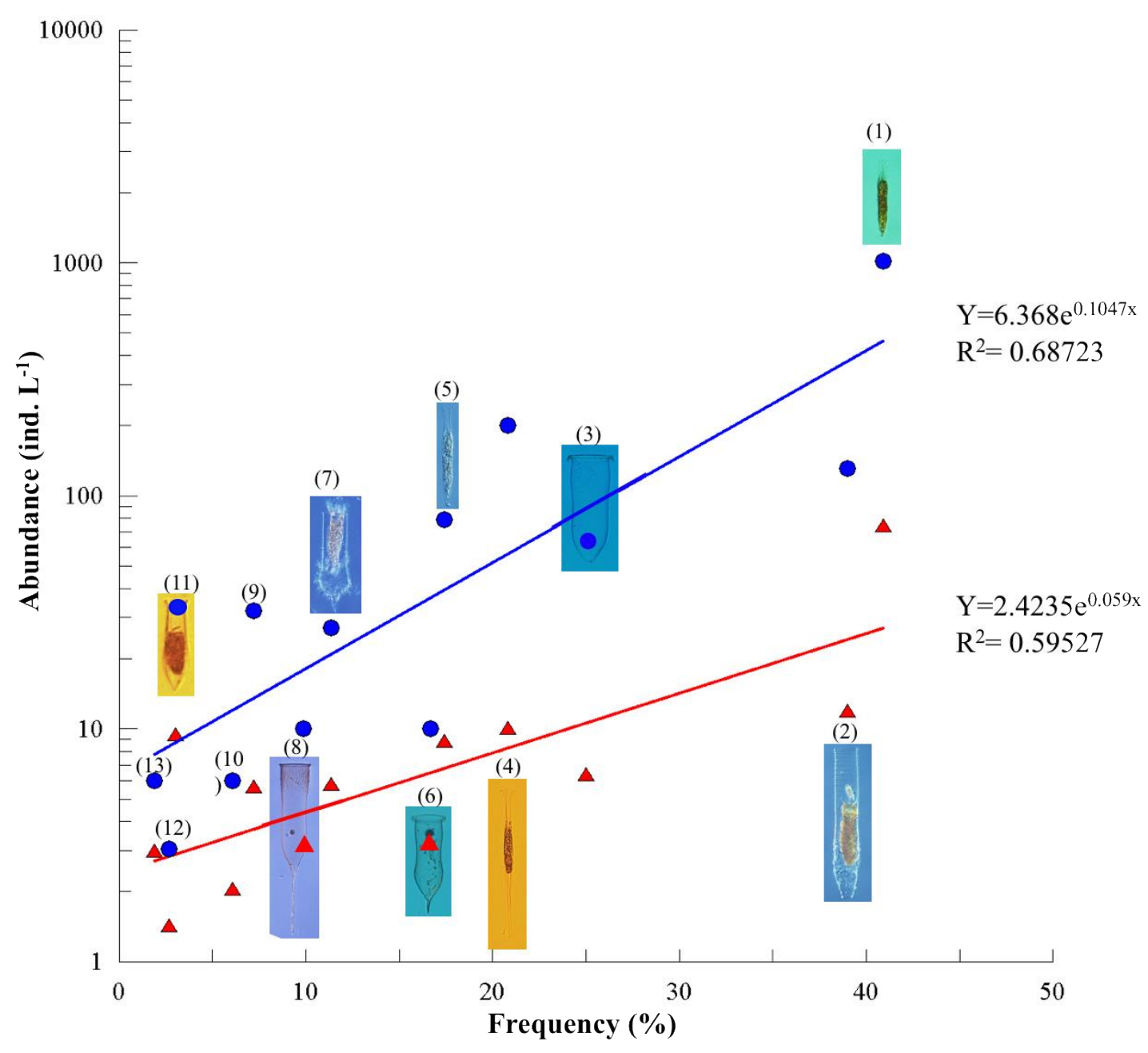

Online Resource 1 Relationship between occurrence frequency and maximum abundance $(\bullet)$, and average abundance ( $\boldsymbol{\Delta}$ ) of each tintinnid species. (1) Salpingella sp.; (2) Laackmanniella naviculaefera; (3) Cymatocylis affinis/convallaria forma cristallina; (4) Salpingella costata; (5) Salpingella faurei; (6) Cymatocylis affinis/convallaria forma drygalskii; (7) Codonellopsis gaussi; (8) Cymatocylis vanhoeffeni; (9) Codonellopsis glacialis; (10) Salpingella acuminata; (11) Amphorides laackmanni; (12) Cymatocylis affinis/convallaria; (13) Cymatocylis antarctica 


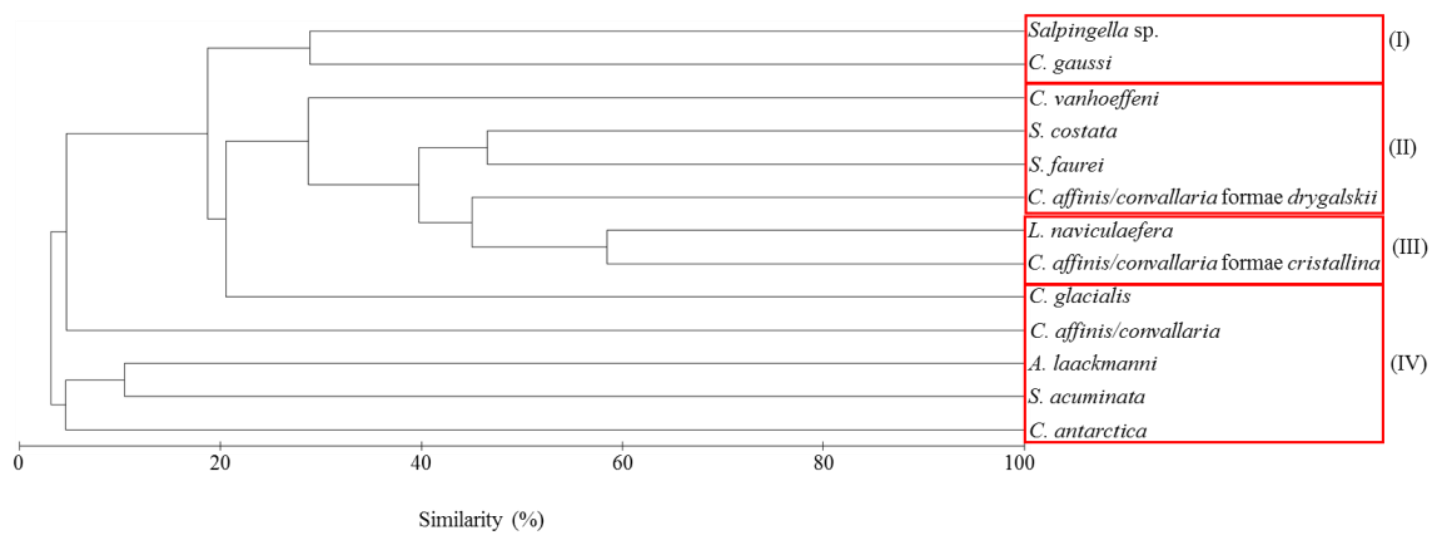

Online Resource 2 Cluster analysis using group-average linkage based on the Bray-Curtis similarity matrix of fourth root transformed tintinnid abundances in all sampling points. (group I) tintinnid species in Pattern 1; (group II) tintinnid species in Pattern 2; (group III) tintinnid species in Pattern 3; (group IV) tintinnid species with no distribution pattern 


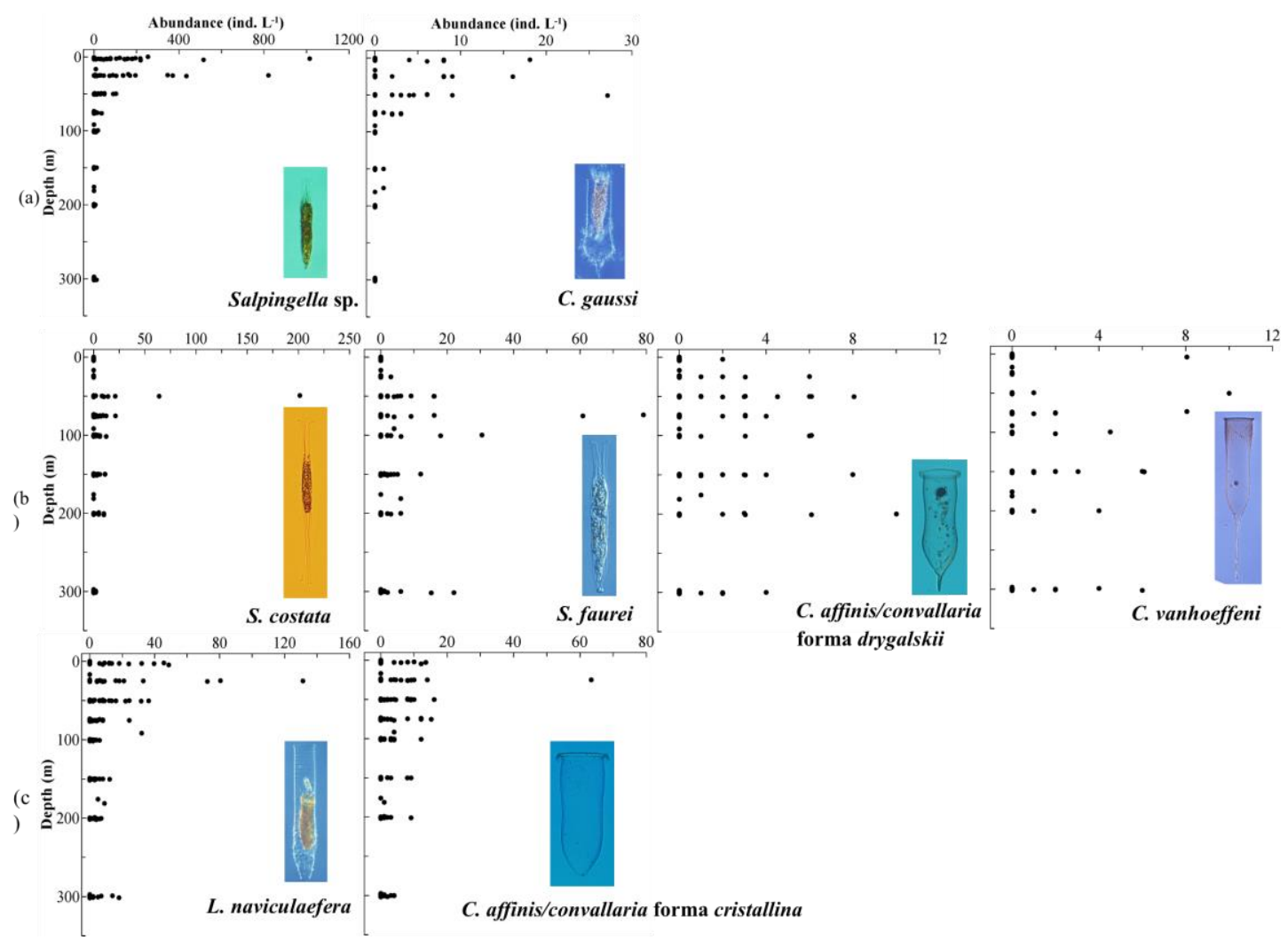

Online Resource 3 Vertical scatter distribution of typical tintinnid species in three patterns. (a) Pattern 1: tintinnid mainly occurred in SSW; (b) Pattern 2: tintinnid mainly occurred in WW; (c) Pattern 3: tintinnid occurred in both $\mathrm{SSW}_{\mathrm{Chl}} a>3$ and WW. SSW: Summer Surface Water; WW: Winter Water; $\mathrm{SSW}_{\mathrm{Chl} a>3}$ : Summer Surface Water with Chl $a>3 \mathrm{mg} \mathrm{m}^{-3}$ 


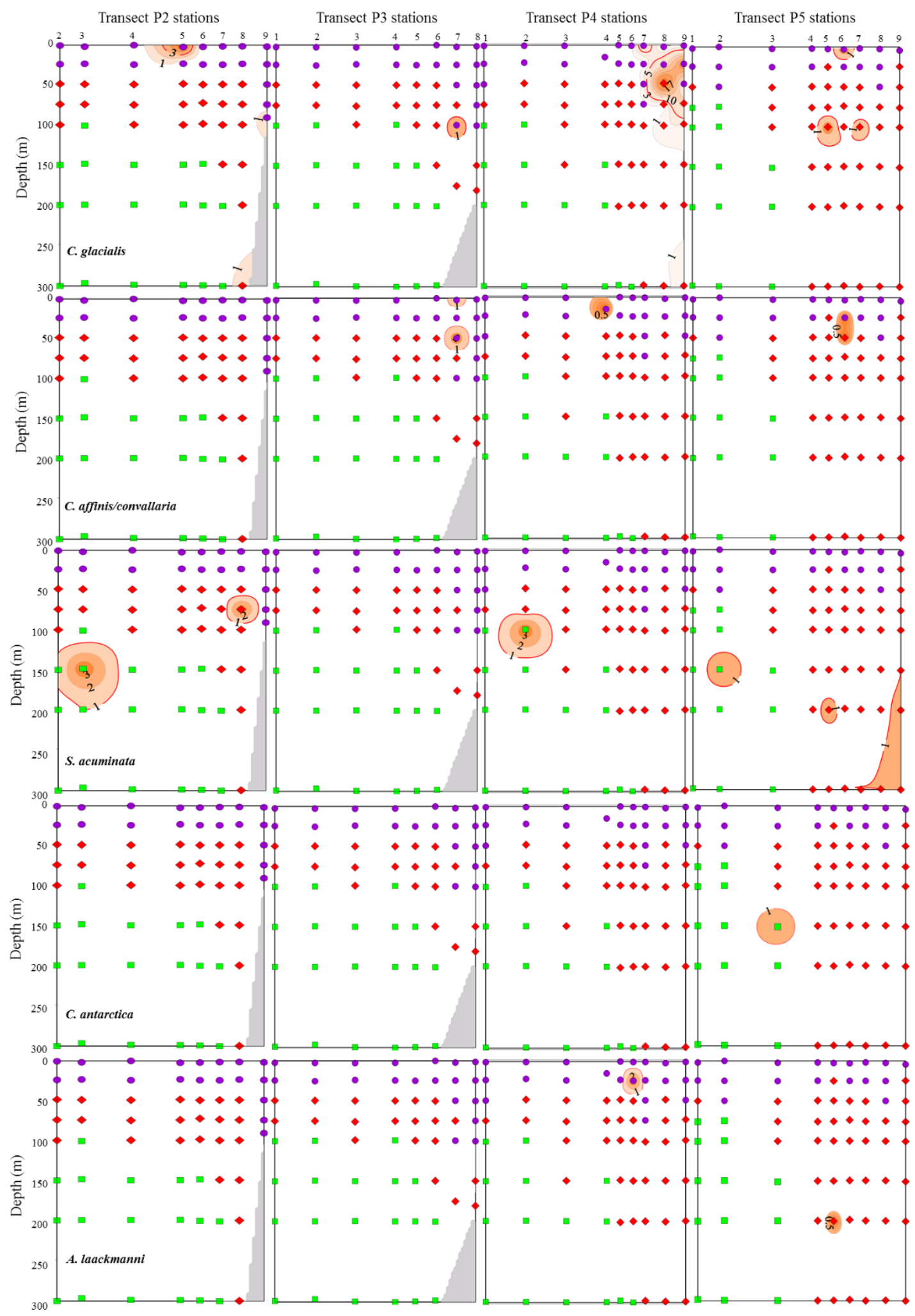

Online Resource 4 Vertical distribution of abundance (ind. $\mathrm{L}^{-1}$ ) of tintinnid species with no distribution pattern in open waters near Prydz Bay. Dot symbols indicate both the depth at which ciliates were sampled and the water masses where samples were collected ( $\bullet \mathrm{SSW}$; WW; CDW). SSW: Summer Surface Water; WW: Winter Water; CDW: Circumpolar Deep Water 


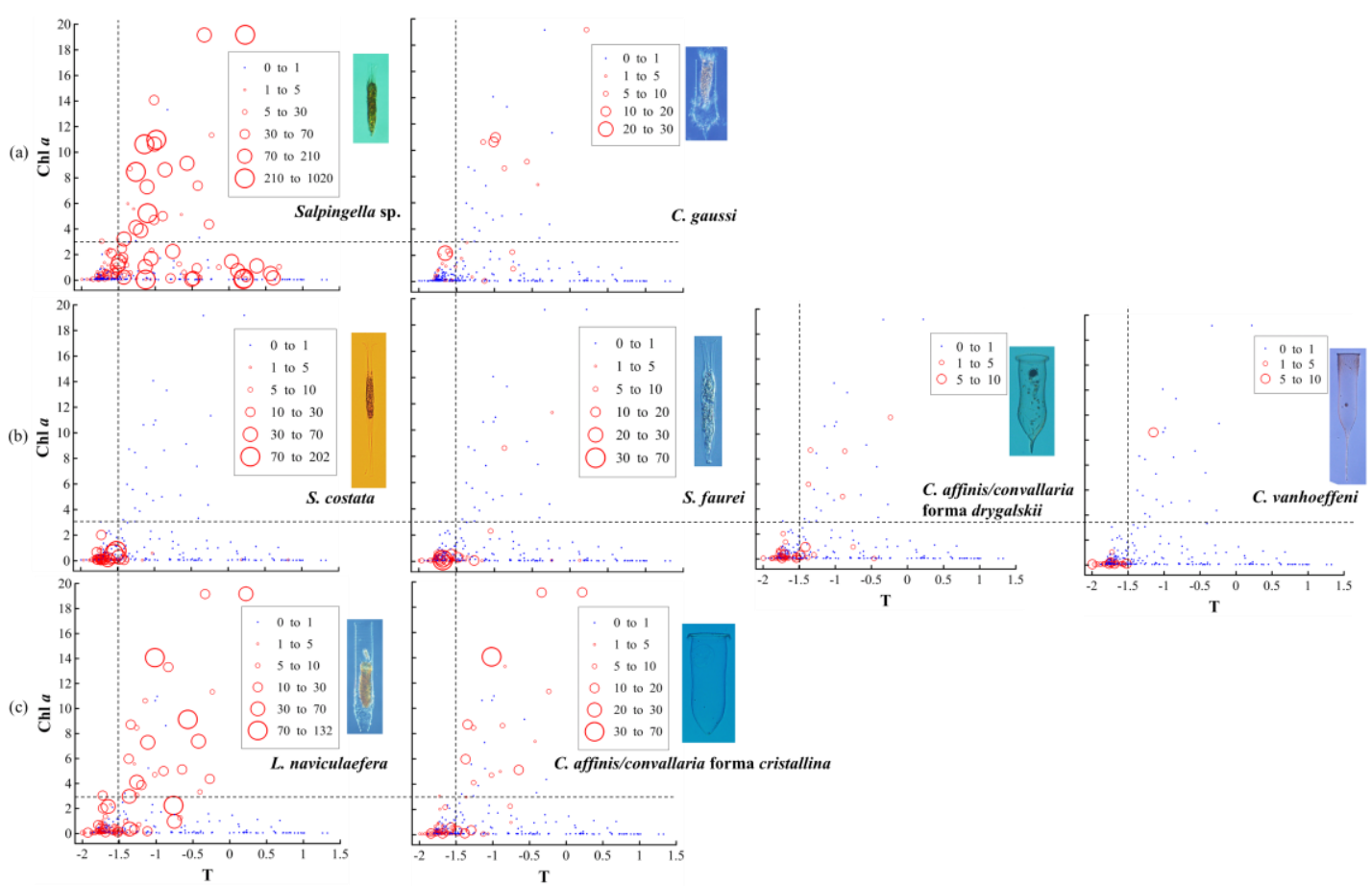

Online Resource 5 Seawater temperature $\mathrm{T}\left({ }^{\circ} \mathrm{C}\right)$ and $\mathrm{Chl} a$ in the sampling points in open waters near Prydz Bay. Different sizes of red circles indicate different abundances (ind. $\mathrm{L}^{-1}$ ) of typical tintinnid species in three patterns in the sampling points. Solid blue dots mean sampling points where this species did not occur. (a) Pattern 1: tintinnids mainly occurred in SSW; (b) Pattern 2: tintinnids mainly occurred in WW; (c) Pattern 3: tintinnids occurred in both $\mathrm{SSW}_{\mathrm{Chl} a>3}$ and WW. SSW: Summer Surface Water; WW: Winter Water; $\mathrm{SSW}_{\mathrm{Chl} a>3}$ : Summer Surface Water with Chl $a>3$ $\mathrm{mg} \mathrm{m}^{-3}$. Horizontal and vertical dashed line indicate $\mathrm{Chl} a$ value of $3 \mathrm{mg} \mathrm{m}^{-3}$ and temperature of $1.5^{\circ} \mathrm{C}$, respectively 